\title{
Managing the Urban Environment of Jakarta, Indonesia
}

\author{
David J. Edelman', Diah Setyorini Gunawan² \\ ${ }^{1}$ School of Planning, College of Design, Architecture, Art and Planning, University of Cincinnati, Ohio, USA \\ ${ }^{2}$ Faculty of Economics and Business, Jenderal Soedirman University (UNSOED), Purwokerto, Central Java, Indonesia \\ Email: david.edelman@uc.edu,diahsetyorini943@gmail.com
}

How to cite this paper: Edelman, D. J., \& Gunawan, D. S. (2020). Managing the Urban Environment of Jakarta, Indonesia. Current Urban Studies, 8, 57-106. https://doi.org/10.4236/cus.2020.81003

Received: February 11, 2020

Accepted: February 29, 2020

Published: March 3, 2020

Copyright $\odot 2020$ by author(s) and Scientific Research Publishing Inc. This work is licensed under the Creative Commons Attribution International License (CC BY 4.0).

http://creativecommons.org/licenses/by/4.0/

\begin{abstract}
This article brings the contemporary thinking and practice of Urban Environmental Management (UEM) to the solution of current environmental problems in Jakarta, Indonesia, which is both the largest city in Southeast Asia and the heart of the world's second largest urban agglomeration, Jabotadebek. Such cities face more immediate problems than those in the developed world and have fewer resources to deal with them. The study first considers the context of Indonesia, and then reviews issues of poverty alleviation, industry, transportation, energy, water, sewage and sanitation, and finance. Finally, it proposes a 5-year plan to help alleviate the urban environmental problems of the city utilizing a real-world database and a limited budget.
\end{abstract}

\section{Keywords}

Urban Environmental Management, Jabotadebek, City and Regional Planning, Developing Countries, Southeast Asia, ASEAN

\section{Introduction}

Urban Environmental Management (UEM) has been receiving increasing attention since 1970 in both developed countries, where it has emerged as a subject of academic research and professional interest, and in developing countries, where it has become increasingly an area of donor concern as well. As a field, it is more like planning or engineering rather than geography, economics or sociology; and it represents an integrated view of environmental problems at city, and increasingly, regional level. Such problems are multi-sectoral (e.g., manufacturing, services, household, etc.), multi-system (e.g., water supply, sanitation, transport, etc.), multi-level (central, regional, local and community) and multi-actor (e.g., government, $\mathrm{NGO}, \mathrm{CBO}$ and private). They require solutions of enormous 
complexity, and those professionals who coordinate the planning, implementation and management of the process must be able to communicate with specialists from many disciplines and professions (e.g., biology, chemistry, engineering, city planning, public administration, social sciences and law) (Edelman, Schuster, \& Said, 2017).

This article focuses on the practice of Urban Environmental Management in developing countries which face more immediate problems than the developed world and have fewer resources to cope with them. It summarizes the findings of a graduate-level workshop that took place at the School of Planning, College of Design, Architecture, Art and Planning, University of Cincinnati, USA from August through December 2019. The objective of the workshop was to prepare students to work overseas in data-poor environments as professional consulting planners. Several lectures were given to set the framework of the mixed class of eighteen domestic and international students to operate in seven collaborative sector-level working groups or teams preparing a 5-year environmental plan for Metropolitan Jakarta, Indonesia, utilizing a real-world database and a limited budget (Edelman, 2020). Jakarta is the political, economic and commercial capital, as well as the largest city, of the world's $4^{\text {th }}$ most populous country. With an estimated 2019 population of 269.54 million (World Population Review-Indonesia, 2020) scattering over more than 17,000 islands and forming over 300 ethnic groups speaking over 700 regional languages, it is the world's largest majority Moslem (87\%) country and is extremely complex. Jakarta is a global city with one of the fastest growing economies in the world. It also has severe environmental problems. The seven teams were poverty alleviation, industry, transportation, energy, water, sewage and sanitation, and finance. Each team looked at the current state of its sector, identified the most important issues facing that sector, prioritized them for action over the 5-year planning period, identified solutions and estimated the necessary funding and sources of those funds. The finance group analyzed the city budget, direct foreign investment and foreign aid to determine if the required financial resources were available and finalized which resources would fund each project.

\section{Indonesia}

The Republic of Indonesia is located in Southeast Asia between the Indian and Pacific Oceans. It is the world's largest island nation, with 1,904,569 square kilometers of land, which makes it the $14^{\text {th }}$ largest country by land area. About $56.7 \%$ of Indonesia's population lives on Java, the world's most populous island. The population density of Indonesia is currently at 140.08 individuals per square kilometer (Ibid.) (Figure 1 and Figure 2).

Despite its large population and densely populated regions, Indonesia has vast areas of wilderness that support a high level of biodiversity (Salikha, 2018). The country is rich in natural resources such as oil and natural gas, tin, copper and gold. Agricultural products include rice, palm oil, tea, coffee, cacao, medicinal 


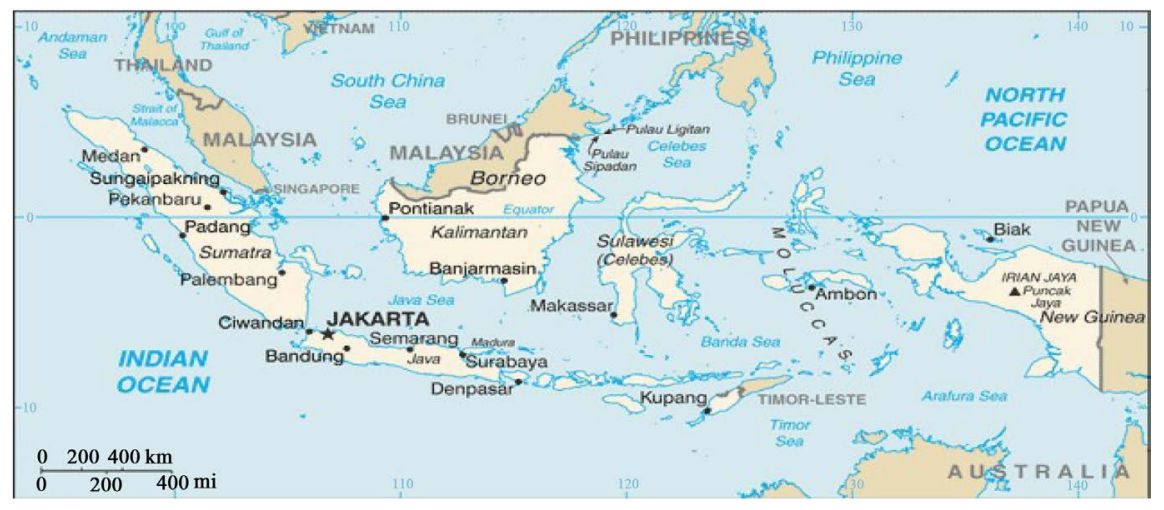

Figure 1. The Indonesian archipelago. Source:

https://www.cia.gov/library/publications/the-world-factbook/geos/id.html, 2020.

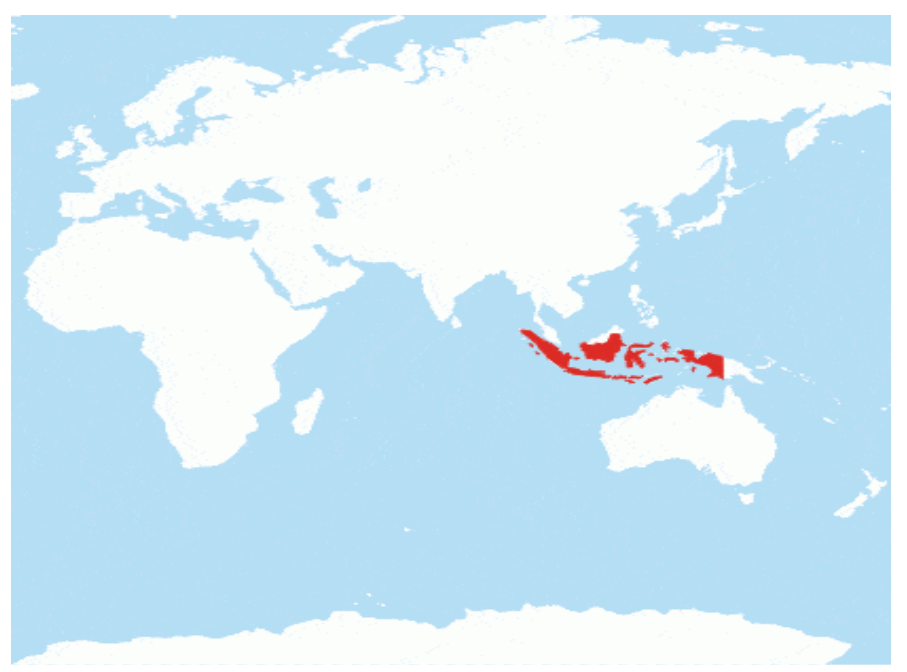

Figure 2. Indonesia's location. Source: https://commodity.com/indonesia/, 2020.

plants, spices and rubber. Indonesia's major trading partners are China, the United States, Japan, Singapore and India. The Indonesian economy is the world's $16^{\text {th }}$ largest by nominal GDP and the $7^{\text {th }}$ largest by GDP at Purchasing Power Parity or PPP (Workman, 2017).

Although Indonesia consists of hundreds of distinct native ethnic and linguistic groups, the largest and politically dominant ethnic group is the Javanese. A shared identity has developed, defined by a national language, ethnic diversity, religious pluralism within a Muslim-majority population, and a history of colonialism and rebellion against it. While Indonesia's national motto articulates the diversity that shapes the country, in recent years the influence of Saudi Arabia has grown, and its Wahabi brand of Islam has led to a rise in conservatism.

\section{Jakarta}

Jakarta or, more accurately, the Special Capital Region of Jakarta (DKI), is the capital of Indonesia, the largest city in the country, and one of the most populous urban agglomerations on earth. Jakarta is the largest city in Southeast Asia. 
It is located on the coast of Java with an estimated 2016 population of 10,638,689, and it is now considered a global city with one of the fastest growing economies in the world (World Population Review-Jakarta, 2020).

The metropolitan area of Jakarta called Jabodetabek (for the initials of the cities of Jakarta, Bogor, Depok, Tangerang and Bekasi) has a population that exceeds 30 million with a total area of 4384 square kilometers (1693 square miles). The Jakarta agglomeration is the $2^{\text {nd }}$ most populous urban area in the world after the Pearl River Delta in China (made up of the cities of Shenzhou, Guangzhou, Foshan, Dongguan and others). The city of Jakarta proper has a very high population density of 14,464 people per square kilometer $(37,460 /$ square miles), while the metro area has a density of 4383 people/square kilometer (11,353/square mile) (Ibid.; Scruggs, 2020).

Although most of Jakarta's population is native to the island of Java, the population of the city is quite diverse in Indonesian terms. This includes the highest number of overseas Chinese in Indonesia and a diverse population from the island of Sumatra. Islam is by far the most common religion in Jakarta, accounting for almost $86 \%$ of the population according to data from the 2010 Census. This is followed by Protestantism (7.5\%), Buddhism (3.3\%), Catholicism (3.15\%), Hinduism (0.21\%) and Confucianism (0.06\%) (Ibid.).

Jakarta is now becoming starved for resources by its ever-growing population. The city (formerly Batavia) was designed to handle 800,000 people when founded by the Dutch, although it is now home to up to 12 million people during the work week, with 250,000 new residents coming to the Jabodetabek region each year (Ibid.). This has given rise to many slums without access to water and other resources. By 2020, the population of Greater Jakarta is expected to grow to 35 million, with mass migration that will further worsen the problems for residents, including poor sanitation, a lack of housing and inadequate transportation. The population of the city is expected to grow to 16 million during the same period (United Nations, 2020).

Indonesia is the largest economy of the Association of Southeast Asian Nations (ASEAN), and Jakarta is the economic nerve center of the Indonesian archipelago. The city generated about one-sixth of Indonesian GDP in 2008 (Huang \& Bocci, 2009). Jakarta's nominal GDP was US $\$ 483.8$ billion in 2016 , which is about $17.5 \%$ of Indonesia's GDP (BPS, 2016). According to the Japan Center for Economic Research, GRP per capita of Jakarta will be ranked at $28^{\text {th }}$ place among the 77 cities in 2030 rising from $41^{\text {st }}$ place in 2015, the largest in Southeast Asia (Nekkei Asian Review, 2018).

Jakarta's economy depends highly on manufacturing and service sectors such as banking, trading and finance. Industries include electronics, autos, chemicals, mechanical engineering and biomedical sciences. The head office of the Bank of Indonesia and the Indonesian Stock Exchange are located in the city. Most of the State-owned Enterprises (SOEs) of Indonesia have their head offices in the city as do major Indonesian conglomerates. 


\section{Poverty Alleviation Sector}

\subsection{Problem Statement}

In Indonesia, people live below the poverty line when their average spending is Rp401,220 (US \$27.72) a month, or around Rp11,000 (US \$0.76) a day. In the capital of Jakarta, the numbers are slightly higher: people are living in poverty when they spend Rp578,000 per month (US \$39.93) or Rp19,000 (US \$1.31) a day. In comparison, the US poverty line income is US $\$ 2145$ or less per month (Renaldi, 2018). The statistics show that the official poverty line is much too low, and it does not represent accurately the truth of how many citizens are struggling financially to live. A researcher from the Institute for Development Economics and Finance (INDEF), Bhima Yudhistira, argues that the poverty data are not enough to explain the reality because instead of measuring income, they only measure household spending (Ibid.). As many as 68 million people are just above, and are at high risk of falling below, the poverty line. $25 \%$ of Indonesians will suffer from poverty at least once in a 3-year period. In fact, many families continuously fall in and out of poverty (Ibid.).

In reality, roughly half of Jakarta is composed of slums. 118 out of 267 sub-districts of the city contain slums, based on the research done by the Agrarian and Spatial Planning Ministry and the National Land Agency working with The World Bank (The Jakarta Post, 2019a). Specifically, 445 neighborhoods, known as Rukun Warga (RW) in the Indonesian governmental system, fall into the slum category. Of all slums, 50\% can be found near rivers, while the rest are scattered along train tracks or underneath highways (Ibid.) (Figure 3 ).

Indonesia's fast-growing economy apparently favors those of the upper middle class. The poor struggle, and that inequality has been a growing concern. The latest report by the Central Statistics Agency of Jakarta published a Gini coefficient

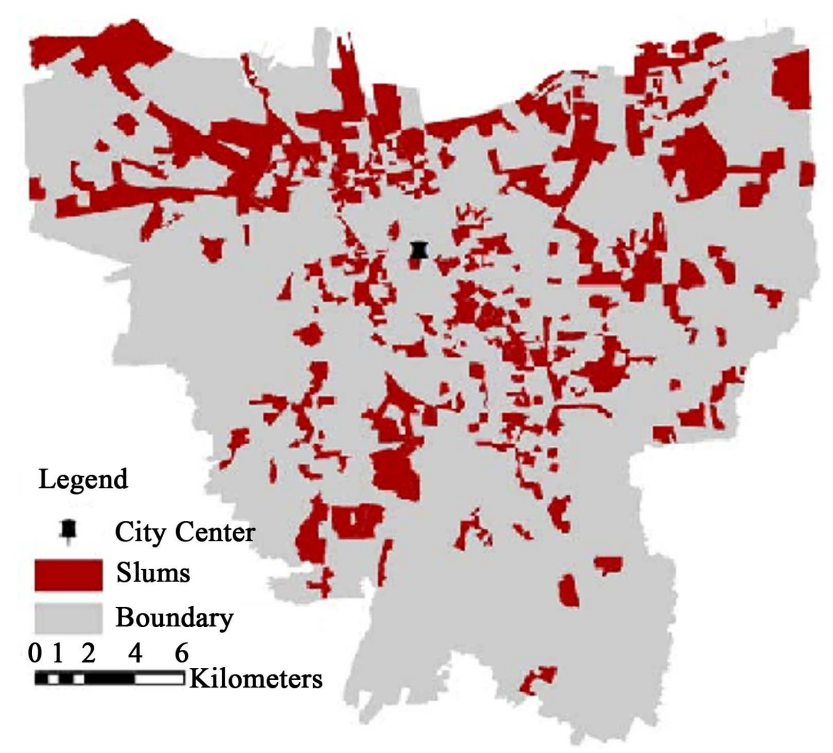

Figure 3. Slum distribution in Jakarta. Source: Kuffer et al., 2017. 
of 0.39 as of September 2018 (BPS DKI Jakarta, 2019). A Gini coefficient is a statistical measure of distribution often used as a gauge of economic inequality, measuring income distribution among a population. While this is an outstanding figure ( 0.0 is perfect equality and 1.0 is perfect inequality), it is not supported by facts in the field. Recently, The World Bank published a report on economic inequality in Indonesia, listing four driving causes leading to the condition: 1) inequality of opportunity in terms of education; 2) unequal opportunities to obtain a better paying job; 3 ) a high concentration of wealth in only a small minority of the population; and 4) low resilience to financial shocks (The World Bank, 2016) (Figure 4).

Based on these findings, this study determined that poverty alleviation projects should also promote decreasing inequality. This involves providing opportunities for education, chances to generate higher income and stronger resilience to financial shocks.

\subsection{Flood Risk Reduction Program}

Flooding is Jakarta's never-ending problem and once again devastating flooding over New Year's Eve and New Year's Day 2020. The Jakarta Post reported Jakarta experienced on New Year's Eve, “... its worst rainfall in over a decade, with heavy rain pouring over the city nonstop until ... morning, causing severe flooding in the capital and its satellite cities on the first day of 2020. The Meteorology, Climatology and Geophysics Agency (BMKG) recorded rainfall intensity on New Year's Eve at 377 millimeters per day, ... the highest in the city since 2007, when rainfall intensity reached $340 \mathrm{~mm}$ per day (Kahfi, 2020).”

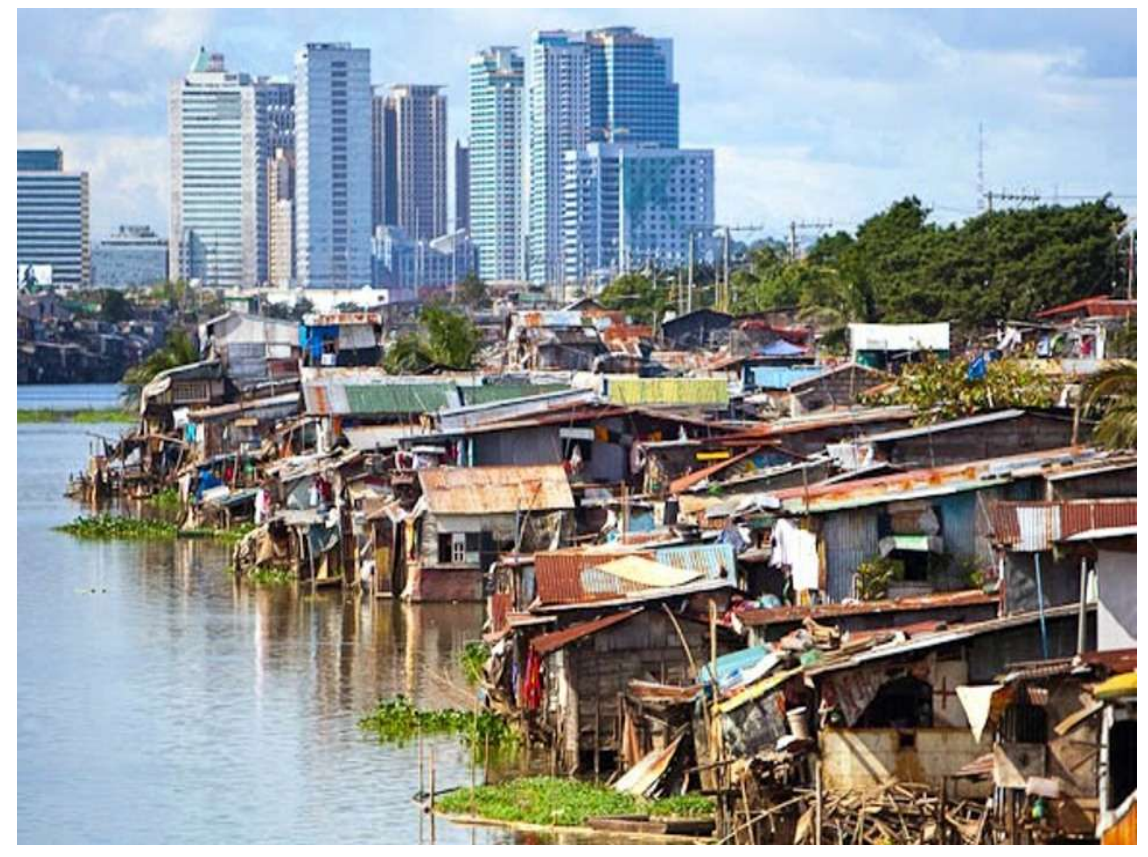

Figure 4. Slum and high-rise buildings standing side by side. Source: Kompasiana.com, 2016. 
The resulting floods inundated the sinking city, leaving dozens dead and thousands homeless. In 2002 as well, the city was hit by a major flood causing total direct and indirect damage of Rp5.4 trillion (almost US \$386 million)and Rp4.5 trillion (almost US \$321 million) respectively (Caljouw et al., 2005). Floods in Jakarta are caused by heavy rains, water runoff from unplanned urban construction and expansion, and the city's geographical features (Octavianti \& Charles, 2018).

Just as with other types of disaster, floods in Jakarta hit lower and lower-middle income groups harder as they cope with major physical and economic losses. For Jakarta's urban poor, disaster means increasing risk for the already difficult life they have. Floods take away their limited assets, sometimes the basic assets necessary to generate income (The World Bank, 2016). As a result, they cannot work and earn money, their children cannot go to school or study properly in the temporary camps for flood victims, and they are at risk for serious diseases. Flooding can take away the time, energy, resources and chances to improve their livelihoods or catch up with the economy. Their children's education will be affected, and this cycle is repeated.

Ideally, flood prevention projects should address the main causes of flooding in Jakarta and create permanent solutions. Nevertheless, the political barriers opposing local government are understood. On that account, this project aims principally to reduce capital risk for the urban poor, thereby reducing what constrains them from climbing the economic ladder.

\section{Project Description}

As a flood risk prevention project, a set of poverty alleviation initiatives for the area is proposed. In Jakarta, makeshift houses were built alongside the river by residents, the majority of whom are illegal dwellers, but there is almost no available land for relocation (Ibid.). For Jakarta, a project that will be divided into different phases over the 5-year planning period is proposed.

\section{Phase 1. Data Generation}

First, interviews will be conducted with 500 households to gather data about previous floods, record community responses and mitigation strategies, list human and capital losses, photograph locations and then upload all the data into a Geographic Information System (Nelson, 2016) for analysis. An integral part of this phase is locating drainage channels around the area (Ibid.). This Phase 1 of the project should take four to six months to complete work on five areas (with 100 household interviews per area) and create a valuable package of data providing a comprehensive view of flood hazards. Data are going to be shared with the government, while experts will analyze the data and provide project recommendations to reduce flood risk, especially related to infrastructure.

\section{Phase 2. Management Strategies Module}

After the data collection and analysis, in Phase 2, the project team will work with the community to create local management strategies before and during 
flood season. Working with NGOs that provide trainers for such coaching, invited representatives from neighborhoods will participate in sixteen weeks of Forum Group Discussions (FGDs) and training on a district level. Meetings will take place once a week, with two to three hours for each meeting. The days shall be decided by consensus, and they can differ from one district to another as each community has its own daily schedule and regular neighborhood meeting.

The meetings will cover action areas for flood hazard management:

- Training on flood prevention, mitigation and preparedness, before flooding occurs;

- Training on responding to floods, and;

- Training on recovery actions (Junaidi, Nurhamidah, \& Daoed, 2018).

Following each training segment, FGDs will be held to gather the completed local flood management strategies. From the FGDs, the team will combine inputs from community members and best practices for flood management, which the community will then discuss and agree upon. Therefore, the result of this project is a module that consists of localized flood management strategies.

In summary, this project will run for the least amount of time possible, i.e., it is expected to be completed in a one-year period. It will start with Phase 1: Data Generation completed in the first six month and continue to Phase 2: Management Strategies Module that will run for 4 months.

\subsection{Modular Housing Project}

A major issue in the slums of Jakarta is safety. The slums are constructed right next to and on top of each other. Andy Brown, a writer for UNICEF, was in Jakarta to help the UNICEF Indonesian office with digital communications, blogging and online video. He recounted his experience in a blog for UNICEF.

In the most densely packed areas of the slums, they reach four stories high. The ground floor slums are relatively well constructed, but as the slums start to build on top of each other, they become increasingly makeshift. Some of the materials used are wood and scrap metal. Sunlight is hard to come by in the slums. Since the buildings are tall and alleys extremely narrow, the inhabitants of the slums rely on neon tubes and bare light bulbs hanging from wires. The air is stale due to poor circulation and there is a lingering smell of garbage and sewage. If the dwelling does not have a toilet, the family has to pay around Rp1000 (US\$ .07) to use the public toilet (Brown, 2013).

\subsubsection{Project Description}

To combat these issues immediately in order to improve living standards as quickly and easily as possible; and drawing inspiration from the "Home for Hope" project of University of Southern California (USC) architecture students (McKnight, 2017), a plan is proposed here to create modular housing. Modular homes are small, individual buildings that can be prefabricated in a factory as one unit. In this specific program, the modular houses will be 200 square feet to 
accommodate an average family of five. The slums that will be targeted first are the ones on the riverbanks because they are the most vulnerable to flood and have increased sanitation issues from the trash in the river. The top five most vulnerable slums in these areas will be the target group for the modular housing. With the slums containing so many people and many undocumented dwellers as well, the people that qualify for the housing project must provide documentation to prove they are citizens of Indonesia, and their children must be enrolled in school. For those who do not qualify due to documentation issues, they will begin a process of obtaining documentation. This will be beneficial to the citizens as it creates new opportunities and will give the government a more accurate reading of the population. Those who do qualify will also begin the process of owning their own plot of land or earn priority for the high-rise affordable housing apartment house that is being built directly in downtown Jakarta.

The design of the modular housing will be a collaboration between architecture students at the University of Indonesia and students from the University of Southern California's School of Architecture. USC already has a collaboration with local incubator Martin Architecture and Design Workshop (MADWORKSHOP) to create the Homeless Studio. MADWORKSHOP provides the capital for the students to construct the modular units. Homeless Studio is a course that gives students real work insight into how the architect can combat homelessness. USC and MADWORKSHOP have experience in designing modular housing for the homeless, and the students from the University of Indonesia have knowledge of Jakarta and the people. Thus, together they can design the ideal housing for the slums.

\subsubsection{Project Implementation}

The plan is to have the design and collaboration process between the local and foreign students take place during the first year, which will be done remotely from the respective universities. In the second year, construction will begin. Some of the USC students and professors will make the trip to Jakarta to help the project along. This process will take about six months in that designs may change once everyone is together and can visit and talk to the inhabitants of the slums that will be receiving the modular housing.

To recap, MADWORKSHOP has previously established a relationship with USC to provide modular housing for the homeless population in California. The collaboration is called Homeless Studio, with the students at USC designing and building, and MADWORKSHOP providing the funds. Since this has been a successful relationship and has had a positive impact on the community, the relationship will be recreated in Jakarta. MADWORKSHOP will establish a Homeless Studio in collaboration with the University of Indonesia. The modular housing project will be overseen and run under the Homeless Studio's Jakarta branch. The design will be developed in collaboration with the USC branch of the Homeless Studio. The modular housing project for the top five vulnerable 
slums, then, will be a collaboration between the Homeless Studio of USC and the University of Indonesia as their first joint project. In the future, the Homeless Studio of the University of Indonesia will be carrying out projects on its own. Those projects will still be funded by MADWORKSHOP. Essentially, MADWORKSHOP will be overseeing two different studios in two different locations.

During the first year, the documentation process will take place. The second year is for the design process. The local architecture students from the University of Indonesia will remotely collaborate with architecture students from the University of Southern California. USC, as noted above, which already has an established relationship with MADWORKSHOP, so they will also be providing design assistance. Finally, the last four years will be the construction process.

\subsection{Village Enterprise Graduation Program}

Jakarta as a center of business, services, trade and finance, offers steady, high income and countless job opportunities. As a result, every year tens of thousands of people migrate to Jakarta for better employment opportunities. A report from The Jakarta Population and Civil Registration Agency predicted a flow 70,000 new settlers into the city in 2015 (The Jakarta Post, 2015a). However, rural immigrants cannot get positions such as office security guards, janitors or drivers with higher monthly paychecks than at home since they do not have identity cards. They would also most likely not have a high school diploma.

Rural immigrants with limited skills and a poor educational background have few choices when coming to Jakarta. Many of them would fill the informal sector; usually providing services and operating small food and beverage businesses. $80 \%$ of those working in the informal sector only went to junior high school or below. Many parts of the informal sector might be considered illegal, but this sector is more than $60 \%$ of Jakarta's economy (International Labor Organization, n.d.). In Jakarta, there are approximately 150,000 street vendors with daily transactions totaling Rp225 billion (US \$20.1 million) (The Jakarta Post, 2019a).

However, with a lack of skills and formal education, a large portion of these vendors are vulnerable to external financial shocks, which can easily disrupt their financial stability and possibly force them back into poverty. The causes of shocks can vary and be price increases, disasters, higher medical expenses, increased children's school charges or additional social expenses, such as weddings, funerals, etc. Some families would spend all the savings they have, and, in most cases, they would be forced to borrow from money lenders at high interest rates.

As one of the solutions, a project is proposed for business and skills training, as well as savings group activity, with the purpose of increasing the opportunity for people to generate income and prepare them to cope with external shocks. It is inspired by a similar project developed and run by an NGO called Village Enterprise since 1987 called Graduation Program. This poverty alleviation program is carried out so participants can escape from poverty (Village Enterprise, n.d.). 
The purpose of this program is first, to allow the participants to maintain a sustainable business through business training. Second, the savings group is also intended for participants to have savings in preparation for future financial shocks, thereby reducing the possibility for them to have to borrow money from loan sharks.

This program is primarily targeted at slum dwellers and vendors located near Jakarta's Central Business District, as they already have market presence. Their small businesses include food shops or warung, motorbike washing, and other small stalls, or walking vendors selling snacks, cigarettes, soft drinks or hot drinks. The fundamental goal is to create a stronger financial capacity for the slum dwellers so that they are eventually able to afford a unit at the government subsidized affordable housing and move out from their makeshift illegal houses.

To operate the program, a team of six people will be formed. An executive director will be responsible for the program overall, while an assistant director will provide administrative and financial management. Two field officers will be responsible for providing business training, and another two will manage business savings groups. Before business training starts, the team will collect data in the five selected districts in order to decide which neighborhoods and families would receive business training. The team will not only interview future participants, but also the head of neighborhood (Rukun Tetangga, usually just referred to as the RT) to avoid misleading data. The team will work in one district per year, with the first month allocated for neighborhood outreach, while the following four months will be for business training and establishing a business savings group. Then, in the next six months, participants will start their business, be mentored and, finally, conduct an evaluation in the last month. These steps will be repeated in the other four districts in succeeding years following the same timeline.

\subsection{Affordable Housing}

Concurrent with the modular housing project, an affordable housing complex consisting of a high-rise apartment building will be underway. There is a great sense of community in the slums. People literally rely on each other for survival. They may be hesitant to move out of the slums and into a high rise because that perceived lifestyle is a drastic change and not for everyone. Keeping this in mind, the idea of community and communal space will be at the forefront of the design for the high rise.

Jakarta is a very densely populated city. The geography of Jakarta is being destroyed by rising water levels due to climate change and the heavy use of groundwater by a very large and growing population. These two factors do not leave many options for affordable housing other than a high rise. There is not much, if any, existing land that can be built upon to expand the perimeters of the city. However, a slim high-rise apartment building can fit into the skyline. As mentioned earlier, moving from life in the slums to city life in a high rise may be 
intimidating, but the high rise will reflect slum life as closely as possible for those who seek that. Revolving around community space, people will still have the sense of belonging and plenty of opportunity for interaction.

In the modular housing project, only the slum dwellers who can provide documentation and have their children in school will qualify. The same will apply to the high rise. Construction will begin on the high rise during the design year of the modular housing, so these two projects will be running congruent with each other. The overall goal is to have people eventually move from the modular homes into the high rise. Since more modular homes are being created than apartments in the high rise, this will be an ongoing issue. The high-rise affordable housing will consist of 1000 units. The construction will take three years to complete. The design will vary from other traditional high rises in that the core concept is to keep the community aspect of the slums so that it is less of a culture shock to the people moving in.

\subsection{Skywalk}

Maclean (2014) has argued that Jakarta's urban poor are an essential part of its economy. As in many other urban areas, people in Jakarta are known to be consumers, and this has allowed the informal sector to grow, providing food and services with lower prices to the middle-class population. This explains the existence of the informal sector co-existing with formal economic activities in the Central Business District (CBD), around train stations, or outside large malls for workers and commuters. One of the strongest parts of the urban informal sector is the sale of food and drinks. Food and drink hawkers can have clients ranging from a man relying on his old bicycle to white collar workers driving fancy cars. Jakarta's has always been known as "the heaven of street vendors". Many food and drink hawkers have found success and attract people from their hometown to work for them and eventually expand the business. A success story comes from one of Jakarta's food hawkers that managed to earn enough money to fund scholarships for children in his hometown.

As much as Jakarta and its people need the informal sector, they have always had a love-hate relationship. Regrettably, the informal sector takes up space on streets, sidewalks, parks and intersections, often, if not always, creating traffic congestion that results in environmental degradation. At one of the busiest intersections, Semanggi, food and drink vendors wait patiently for workers and students on their way home, blocking walkways. Still, parts of the working class in the upscale areas rely on these street vendors for their daily food as they offer a cheap option.

Therefore, it is clearly necessary to provide affordable goods and services for the urban population, especially the middle-income population; regulate street vendors in order to avoid misuse of other public amenities; and promote the economic development of the lower income population through a regulated business framework. 
In order to answer this challenge, skywalks are recommended as the last project for poverty alleviation. A skywalk was first introduced by Ridwan Kamil, former mayor of Bandung, a city $180 \mathrm{~km}$ southwest of Jakarta. Having a similar design to that of the Highline in New York City, the Bandung skywalk is an elevated structure above the road and is designated for pedestrians. Named Teras Cihampelas (Cihampelas Terrace), the 450-meter walkway was part of the government's effort to accommodate street vendors who previously jammed the sidewalks, causing traffic congestion in Cihampelas Road (The Jakarta Post, 2017) (Figure 5).

For this project, it is proposed to construct skywalks that will connect the $\mathrm{CBD}$ and nearby commuter train stations. This idea is inspired by the trend of Transit Oriented Development (TOD). TOD is an approach that advocates development expansion around stations, connecting pedestrian and non-motorized modes of transportation with customer-based local services and public transit (ITDP, 2017). Creating skywalks will be a solution to land scarcity and high prices in the city center. More importantly, the skywalks will be designed to accommodate street vendors, providing them with venues for business and customers who are daily commuters. They will be located near offices and be close enough for workers to access during lunch time. To put it differently, skywalks will provide space for community engagement and productivity (Nabilah, 2018).

The pilot project will be programmed for five years, with the first year a preparation year where the project team consults with local government, collects data for street vendors in the area, conducts socio-economic analysis, and finalizes arrangements with contractors. One skywalk will be constructed in each of the second, third and fourth years and two in the final year. In total, five skywalks will be built in this pilot project. The skywalk locations should be a part of the team's consultation with the government, and they should be near to districts where Modular Housing and the Graduation Program take place.

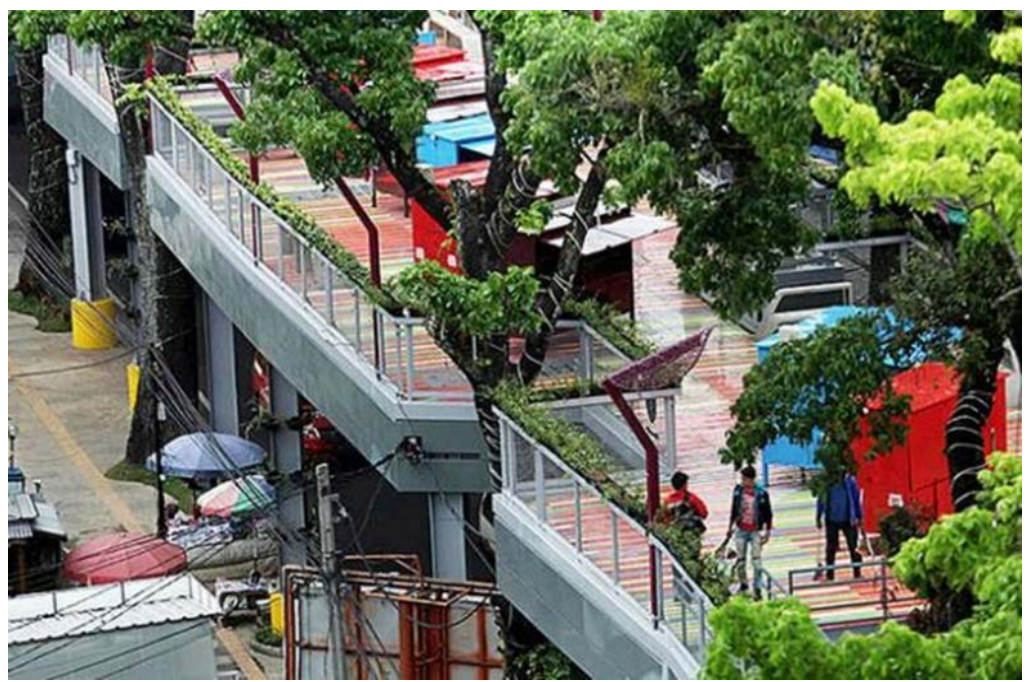

Figure 5. Teras Cihampelas skywalk in bandung. Source: Kompas.com, 2017. 
Each skywalk will be 200 meters long and 15 meters wide to allow pedestrian access and space for business. It is proposed that each skywalk can cater to 50 100 vendors, depending on the area needed for each vendor. Of all vendors that may open a business, $50 \%$ of the slots will be allocated to Graduation Program graduates. The rest of the spaces should go to street vendors located near each skywalk with the purpose of clearing out sidewalks and intersections. To reserve places for nearby vendors and avoid fraud, selection will refer to data that have been gathered before construction begins. More importantly, the slots will first be prioritized for Jakarta residents confirmed by their official identity cards. Finally, the selected vendors will have to pay a monthly administrative fee of US $\$ 100$.

\subsection{Further Considerations}

Slums and inequality are problems that are connected to others, such as flooding, overcrowding and poor health. These are the larger issues that need to be addressed, not only by Jakarta's local government, but the central and regional governments as well. People move to Jakarta because rural areas do not provide enough adequate jobs. If attractive economic opportunities were available in villages, the residents would be less likely to consider moving to Jakarta (The Jakarta Post, 2015a). Without improved opportunities in rural areas, problems with illegal slums in Jakarta will be difficult to address because when current residents move to better housing units, newcomers will fill their empty spaces. Nevertheless, addressing this problem in Jakarta would require a strong commitment by the government to enforce regulations. Without that, the situation will only worsen. The government needs to take aggressive action in order to redeem the lives of the people who are stuck in the slums because the system is not only not working for them, it is working against them. It is time to start working for the people that have been abandoned through a government that is more than capable of making these changes.

\section{Industry}

\subsection{Context: Industry in Jakarta}

\subsubsection{History}

Jakarta has long been an important trading destination. It was taken by force by the Dutch East India Company in the late $17^{\text {th }}$ century, and the Dutch used the land as a fortress with warehouses for the company. Jakarta, called by the Dutch Batavia, both then and now, was used as a major port for the lush island of Java. The Dutch used the land to extract coffee, tea, spices, rubber, palm oil and other "cash crop" products for the European continent. Jakarta became the economic center of the nation (Widodo, 2006).

Following Indonesian independence in 1949, economic policies shifted to self-sufficiency for agriculture and the export of fossil fuels. President Suharto nationalized some industries, including oil, natural gas and banking. This period 
was marked by economic growth, but also reliance on the oil industry. The late $20^{\text {th }}$ century was marked by rapid industrialization and the subsequent urbanization of the country. Beginning in the late-1960s, Indonesia's economy saw an average growth rate of 7\%. Following the 1997 Asian Financial Crisis, Indonesia went through a period of economic decline and civil unrest. Rising tensions led to Suharto's resignation in 1998, ushering in a new economic way in Jakarta and Indonesia (Ibid.)

\subsubsection{Recent Development Conditions}

By the turn of the $21^{\text {st }}$ century, the political environment had settled down, and economic growth had stabilized, though it has failed to reach the pre-Asian Financial Crisis levels. From 2000-2017, the average economic growth rate was 5.3\% (Hofman et al., 2004).

Currently, Indonesia's inflation rate is declining, and Gross Domestic Product (GDP) per capita is rising. Economic indicators point to a time of economic stability with the potential for increased growth. Despite this, Indonesia's economy is having difficulty taking off, and Real GDP Growth has hovered around 5\% for the past five years (Australian Government Department of Foreign Affairs and Trade, 2019). In order to realize this potential, Indonesian industry needs to adapt better to a globalized world, positioning itself to become a leading economy in the future.

As of 2019, Indonesia was ranked $73^{\text {rd }}$ on The World Bank's Ease of Doing Business Index. The World Bank ranks countries on the business-friendliness of regulations. This index provides objective measures of business regulations and their enforcement. Indonesia's ranking is low, when compared to other countries in the region. For comparison, Singapore is ranked $2^{\text {nd }}$, Malaysia is $12^{\text {th }}$, and Thailand is $21^{\text {st }}$. The only country in the region with a worse ranking is the Philippines, which is ranked $95^{\text {th }}$ (The World Bank, 2016).

As one of the world's largest nations by population, Indonesia belongs to many international organizations. It is a member of ASEAN (Association of Southeast Asian Nations), and Jakarta hosts its Secretariat. Membership in ASEAN allows Indonesia to participate in free-trade agreements with neighboring countries, and visa-free travel within the region. Indonesia is currently the only Southeast Asian nation that is a member of the G20. This membership gives the country an advantageous position with trade partners such as the EU, India and China.

Indonesia is in a unique position. It is Southeast Asia's largest economy and is a young country. Over half of the population is under 30 years of age. Along with much of the world, Indonesia (and Jakarta) is moving towards a more integrated digital economy. This global trend is known as Industry 4.0, a shift toward cyber-physical systems in manufacturing processes, such as automation and cloud computing. Aiming to become a top ten economy by the mid-2 $1^{\text {st }}$ century, the Indonesian Government has enacted the Making Indonesia 4.0 in- 
itiative to support the manufacturing sector (BKPM, 2019). This, along with the proposed reforms discussed later in this section, should bring Indonesian industry to the forefront and provide sustainable economic growth for now and years to come. The Indonesian Government acknowledges the problems the country has with its business environment and needs to continue to create and implement policies to support businesses and ease the risks of doing business.

\subsubsection{Outlook}

The goods produced in Indonesia are neither unique nor complex. The main industries are food products, textiles and apparel, chemicals, automotive, electronics, and petroleum related products. Combined, these industry sectors produced 74.75\% of Indonesian output in 2017 (Business Sweden, 2018). Moreover, Jakarta lacks adequate infrastructure, and the environmental outlook is dire. This has led to the planned 2024 relocation of government functions from Jakarta to a newly constructed capital in East Kalimantan on the island of Borneo. The relocation of government will provide some relief, but will not stop the growth of Jakarta or alter its status as the most important economic hub in the country, and, therefore, the roadmap laid out for advancing the economy of the country in Making Indonesia 4.0 is of utmost importance to the city. This plan focuses on net export and cyber-physical systems as the next step in economic growth (Ibid.).

The Port of Tanjung Priok is the largest port in Indonesia. Located in North Jakarta, the port is crucial to the Indonesian economy. In order to keep up with demand, the port is currently undergoing an expansion aimed at increasing capacity from 5 million twenty-foot equivalent units to 18 million units. This expansion will work as a catalyst and help Indonesia's economy benefit from a demographic dividend: accelerated economic growth due to a lesser percentage of the population being dependent on others and an increase in the labor force. This is a result of a decrease in fertility. The dependency ratio is projected to keep improving until 2025, at which point the window to take advantage of this dividend will slowly start to close (Hayes \& Setyonaluri, 2015). This makes the present a prime time for economic development.

\subsection{Problem Statement}

Indonesia is currently a middle-income economy. As the global shift towards a digital economy continues, places with developing economies must adapt. Indonesia has expressed a desire to be an upper-middle income, and then an upper income, country. In order for the country to move up in income, changes must be made to the economy. Moving towards a more digital world with increasing complexity requires adaptation from both the government and industries.

\subsection{Selected Priorities}

The three priorities selected to invigorate the industrial sector are diversifying 
and increasing complexity in the manufacturing sector; training youth for a globalized and high performing economy; and continued support and enhancement of the service sector. These are discussed in detail in the following paragraphs.

\subsubsection{Diversifying and Increasing Complexity in the Manufacturing Sector}

Indonesia is one of the world's largest manufacturing economies. Manufacturing accounts for the employment of 25 million workers and $20 \%$ of GDP, totaling US $\$ 203$ billion in 2017. Manufacturing output has grown steadily in the past five years, but while industry is growing in Indonesia, it is still not as successful as it could be. There is potential for the manufacturing sector to grow, both in terms of output and GDP (Business Sweden, 2018). Manufacturing has long been called an engine of growth, and Indonesia is not exempt from this (Asian Development Bank, 2019).

Indonesia has an opportunity to move towards a more diverse manufacturing sector and to upgrade how it produces and exports goods. Indonesian manufacturing is still focused on resource-based products, such as its food and beverage industry and its production of crude palm oil. To succeed in the increasingly competitive global market, Indonesia will need to develop niche and specialized sectors, in which it can dominate and have a comparative advantage. Most of these niche sectors should come from the electronics and chemicals sectors, which already have a relatively higher complexity than other Indonesian products (Asian Development Bank, 2019). To increase Indonesia's competitive advantage in domestic and foreign markets, the government has adopted the Making Indonesia 4.0 initiative. It is a comprehensive approach towards moving Indonesia and its economy towards the economies of now and in the future. Some of the highlighted priorities are implementing digital infrastructure, preparing the country and its industries for emerging technologies, changing education curricula to align with industry needs, and revising relevant regulations, including tax holidays, subsidies and funding (Business Sweden, 2018). Figure 6 shows prioritized activities to expedite the implementation of Making Indonesia 4.0.

The manufacturing sector is not as diversified as it should be for maximum economic output. Most of Indonesia's exports do not have a competitive advantage. As Figure 7 illustrates, they are standard products that other countries, especially neighboring countries, are also exporting. As of now, Indonesian manufacturing produces unsophisticated products. The main sectors for manufacturing are food and beverages, chemicals, textiles, automobiles and electronics. These industries were responsible for two-thirds of manufacturing output in 2017.

Changes and innovations in the manufacturing sector will have the biggest effect on Jakarta and the island of Java. As seen in Figure 8,70\% of the total value added from manufacturing comes from the island of Java. Jakarta, as the economic and manufacturing center of the country, benefits most from economic policy changes. While the plans outlined in Making Indonesia 4.0 look at Indonesia 
Prioritized Activities To Expedite The Implementation of Industry 4.0

Enhance domestic raw material processing

2 Redesign industrial zones by building a nationwide industry zoning roadmap

Increased involvement in global

3 sustainability trends such as Electric Vehicles and Renewable Energy

4 Empower SMEs with new technologies

5 Develop national scale digital infrastructure
Engage top global manufacturers to

6 accelerate knowledge transfer

Upskill human resources by

7 redesigning education curriculum

Collaborate with universities and

8 private sector to establish innovation ecosystems

9 Prepare incentives for technology investments

10 Realign relevant regulation and policies to support the roadmap

Figure 6. Indonesian priorities in Making Indonesia 4.0. Source: Business Sweden, 2018.

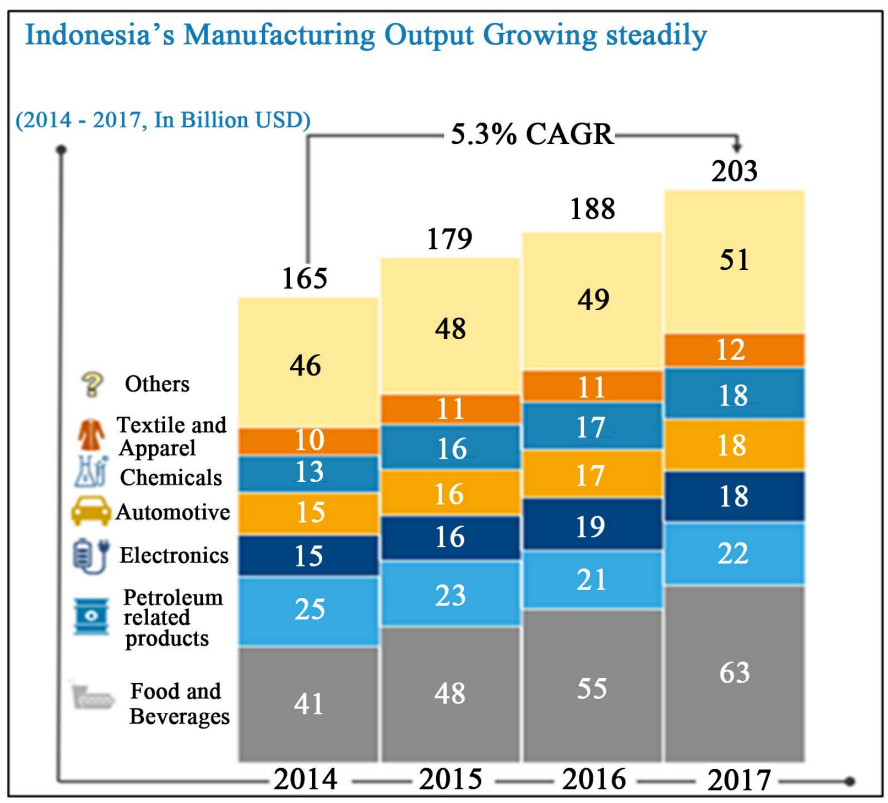

Figure 7. Indonesia's manufacturing output 2014-2017. Source: Business Sweden, 2018.

as a whole, the reader should remember the place of Jakarta in the Indonesian economy.

For the Indonesian Government to support the manufacturing sector, including increasing the diversity and sophistication of manufacturing products now and in the intermediate term, there are policies that can be effective, but also cost little to the Indonesian people. The Indonesian Government has already taken steps to improve the business environment; however, more can and should be done. Many of the reforms currently are general tax reforms. New policies should target specific sectors, especially the five sectors highlighted in the Making Indonesia $4.0 \mathrm{plan}$. These policies should allow private business to do what it 


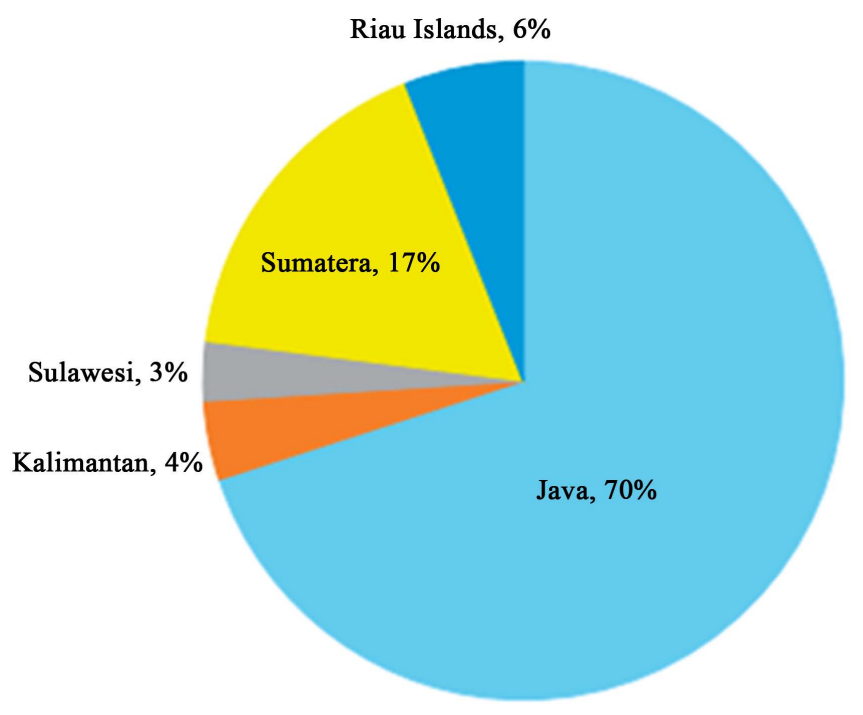

Figure 8. Geographical distribution of manufacturing as a \% of total value added. Source: Asian Development Bank, 2019.

does best: innovate and develop better ways to send products to market. By tailoring tax incentives and structures, while having a government commitment to encourage smart business growth, Indonesia should see its future become more prosperous.

Developing the niche-products the manufacturing sector needs is dependent upon the individual industries and companies themselves. The Indonesian Government, however, must develop a better understanding of what the manufacturing sector requires. Currently, a lack of knowledge at the governmental level of what manufacturing needs is holding the sector back. The government should hold Industry Summits to learn more about specific challenges the sector faces. There is opportunity for collaboration between government and industry, but a mutual understanding must exist first.

In conclusion, to diversify and increase the complexity of the manufacturing sector, the government should continue its current efforts, in addition to furthering its efforts and understanding. Targeted tax reforms towards specific industries, increasing the ease of doing business (which will also assist the service industry), and the continuation and implementation of the Making Indonesia 4.0 reforms should assist the manufacturing sector. While challenges in the sector remain, the proposed government changes should assist in advancing the manufacturing sector into the modern $21^{\text {st }}$ century economy and beyond.

\subsubsection{Training Youth for a Globalized and High Performing Economy}

The Indonesian Government has made it clear that focusing on technical and vocational skills is a top priority in the Making Indonesia 4.0 plan. These educational institutions are key to providing Indonesians with the high-level skills currently at a deficit in the labor market. They have taken steps toward increasing enrollment by ceasing to grant new university applications, aiming to steer 
those who would have established additional universities to instead establish new polytechnic schools. Currently, there are fewer than 300 polytechnic schools nationwide and only 55 million skilled workers. By 2030, the manufacturing sector in Indonesia is expected to have a demand for 113 million skilled workers (Arbi, 2019). Pursuing an education at a polytechnic or vocational school is seen as undesirable by the majority of post-secondary-education-bound Indonesians. Some serious change is needed.

In 2012, the Indonesian Government established the Polytechnic Education Development Program (PDEP) in order to strengthen polytechnic education in Indonesia. It is primarily funded with a loan from the Asian Development Bank (ADB), as well as the government budget and aid from Canada (Ibid.). The program focuses on altering the education and training provided at polytechnic institutions to be more in-line with real industry needs. This existing system needs to be expanded. Indonesia should aim to increase the loan amount from the $\mathrm{ADB}$, seek more aid from Canada, and allot a larger percentage of the state's budget to the PDEP. Utilizing these expanded funds to focus on polytechnic education in the Jabodetabek region would improve training quality and capacity in the nation's most important manufacturing hub.

The combined pressure from employers seeking more workers and students seeking education would provide an incentive to the private sector to create new polytechnic and vocational schools. In order to take advantage of this fully, the PDEP should encourage new and existing polytechnic and vocational schools to deliver quality training and education through the establishment of new grant and scholarship programs from the Ministry of Research Technology and Higher Education. Grant distribution would be based on factors such as the employment rate of graduates and the percentage of total enrollment that are women. Scholarships should be awarded on a monetary need basis.

\subsubsection{Continued Support and Enhancement of the Service Sector}

Indonesia has the potential and desire to move towards a more advanced economy. As economies develop, an important transition is from primary and secondary sectors to tertiary sectors. Tertiary sectors are those that provide a service, as opposed to the raw material production, extraction and manufacturing seen in the primary and secondary sectors. Indonesia has been shifting from the primary sector, as employment in agriculture and mining continues to fall.

The service sector is now the largest employer in Indonesia, accounting for $48 \%$ of employment. This is up from one-third of all employment in 1990 (Asia Link Business, n.d.). Moreover, between 2010 and 2017, the service sector in Indonesia grew at an average rate of $7.1 \%$ (Aisyah, 2019). The Trade Ministry's Director General for International Trade Negotiations, Iman Pambagyo, has emphasized the importance of the service sector to the Indonesian economy. $\mathrm{He}$ has stated that when economies develop further, the role of the service sector becomes more important, especially with Indonesia moving towards the Making 
Indonesia 4.0 initiative (Ibid). When compared to developed countries, Indonesia has a low share of employment in services. According to the World Bank, high income countries have an average of $75 \%$ employment in the service sector. Middle income countries, such as Indonesia, have a service sector employment average of $46 \%$, with upper middle-income countries averaging 52\% (The World Bank, 2019).

In order to support the growth of the service sector, Indonesia should focus on increasing trade within that sector, increase support for the sector through policy, continue to reduce barriers to doing business, and enhance online government services. Much of the responsibility for growth falls on the service sector itself. The role of the Indonesian Government should be to facilitate and support the service sector, while allowing the private sector to innovate and add value to the economy.

Increasing trade within the service sector is a marked priority of ASEAN. By increasing trade, value can be added, and gaps in Indonesia's current service sector can be filled. The current gaps are partially a result of a lack of skills needed for a $21^{\text {st }}$ century economy. Most of the trade within the Indonesian service sector comes from domestic trade and demand. Currently, less than a quarter of the value added to exports from services comes from abroad. Comparatively, in the neighboring countries of Thailand and Malaysia, almost half of value added from exports comes from services (Damuri, 2016).

Within Indonesia, the government needs to increase its support of the sector, particularly with easing barriers to entrepreneurship and investment, and, overall, it should increase the ease of doing business. According to The World Bank, greater ease of doing business is associated with higher levels of entrepreneurship. These connected factors can be solved by similar solutions aimed at easing the burden of owning and operating a business within Indonesia.

Unlike the manufacturing sector, the service sector at present does not have a comprehensive policy to enhance it (Ibid). The government currently has the Indonesia Service Dialogue (ISD), which serves as the mechanism for a dialogue on services. The ISD brings together high-level public and private stakeholders for a conversation about the sector as a whole, as well as its individual components. Thus, the ISD exists to "promote growth and greater efficiency in Indonesia's service sector." (Ibid). Instead of just holding a dialogue, the ISD should use its strength of collaboration to influence public policy and lobby for more cooperation between the government and business leaders.

\section{Transportation}

\subsection{Transportation Background in Jakarta}

Jakarta has a high and densely packed population that has affected how transportation activities have been shaped. Furthermore, the city has been developing rapidly, and this is another key factor that affects current transportation activi- 
ties. Additionally, as the city has expanded, the average trip distance has almost doubled. In 1985, the travel distance to school was $2.7 \mathrm{~km}$ but increased to 5.5 $\mathrm{km}$ by 2000 , and the travel distance to work rose from $6.7 \mathrm{~km}$ to $9.6 \mathrm{~km}$ in the same period (Susilo et al., 2007). Consequently, travel mode choices were affected, and people began in greater numbers to purchase their own automobile for convenience. This increased use of personal automobiles for transportation has affected the transportation facilities that the city has prioritized. Transportation projects began to focus on automobiles; thus, roads and highways were emphasized.

The uncontrolled motorization not only has affected travel, but also the economic, social, psychological and health aspects of urban life. Air pollution became an increasingly critical concern due to its effects on the health of Jakarta's residents. As a result of these developments, Jakarta is now considered one of the most congested cities in the world (Ibid.). Nevertheless, rapid urbanization is still occurring in Indonesia, and, as was noted earlier, Jakarta is now the largest city in Southeast Asia.

\subsection{Jakarta's Transportation Infrastructure}

This section describes the current state and potential of Jakarta's public transportation systems, most notably the capital's Bus Rapid Transport (BRT) network TransJakarta. First, a brief background of Indonesia's and Jakarta's transportation infrastructure is given. The potential ramifications of this background are discussed, and a detailed look into why TransJakarta is critical to Jakarta's transportation network is argued. A key TransJakarta project, as well as its funding, is outlined at the end of the section.

Since the 1997 Asian Financial Crisis, both public and private support for transportation infrastructure, as well as total investment in them, has been alarmingly low. Prior to 1997 , approximately $8 \%$ of GDP was invested in infrastructure, versus an estimated 3.5\% in 2016 (Leung, 2016). This urban infrastructure investment gap continues to widen, as demand for efficient public transportation, particularly in Jakarta, continues to increase rapidly. While the demand has increased, urban infrastructure investment, as a share of GDP, has remained at about $3 \%$. Currently, it's estimated that $7 \%$ to $7.5 \%$ is the share necessary to cover the required infrastructure investments and capital replacement for these projects (Ibid.). Both the slow pace of transport infrastructure development and its poor quality in Indonesia can be attributed to this underinvestment. Jakarta's transportation networks suffer a myriad of issues alongside these as well. There have long been neglected policies and institutional reforms in the capital. The city's various transit modes suffer across the board from outdated networks and underutilized deployment. They also have insufficient transport infrastructure, the BRT and local bus systems especially, as they share the same infrastructure as cars and motorbikes. This infrastructure is in real crisis with mainly car and motorbike traffic congesting the larger urban nodes, and the city's walkability is 
almost non-existent as a result of dwindling public space along these nodes. A lack of urban rail, along with this congestion, has resulted in daily gridlock across the capital, along with alarming pollution rates, which have ultimately greatly reduced the quality of urban life in Jakarta. This congestion also negatively affects the country's investment climate and GDP, as there is lost productivity in these traffic jams and gridlock.

\subsubsection{TransJakarta}

Jakarta currently has four major transit systems in place, TransJakarta BRT, Jakarta MRT and two commuter rail lines, including the KRL. There is also a fifth LRT system that opened in November 2019. With the growth of these transit systems, the capital is becoming less car dependent. While the rail systems are increasingly important to the capital's transportation infrastructure, Jakarta's transportation future will ultimately depend on the success of TransJakarta, the city's robust Bus Rapid Transit System. It has the second-highest ridership of all transit systems, but the BRT has opportunities for growth and continued ridership that the other transit networks do not. The system celebrated its fifteenth year of operation as the first BRT system in Southeast Asia in January of 2019. Extending over $240 \mathrm{~km}$, TransJakarta is the world's longest BRT system, and, with a daily ridership of over 800,000 people, the network continues to spread while its popularity also continues to grow (ITDP, 2019).

\subsubsection{Affordability}

Even with the increased amenities it has provided in recent years, the most critical factor for TransJakarta has been its affordability. It has remained low cost, with current tickets at roughly Rp3500, equal to US \$0.30. Riders now have access to a mobile app that details bus schedules, which has improved the network's efficiency tremendously. There has been a cultural shift for drivers and riders of TransJakarta in recent years, as the system is adjusting to enforcement of its specified stops and no longer picks up passengers at any given point along a route. It has certainly taken many riders time to adjust. However, it is critical that the BRT system be structured in this manner.

\subsubsection{Issues of Concern}

There are many issues facing TransJakarta going forward. There needs to be a strong focus on accessibility to the network, as queue times are often extremely daunting to potential riders. The bus stations themselves need to be redesigned to accommodate more riders, while also infusing public space elements into the design. There are particular groups, such as handicapped persons or the elderly, that are unable to access many of these stations. Basic infrastructure needs to be reconsidered, such as the pedestrian bridges and even the sidewalks. All stations need to embrace the concept of street-level boarding, which can greatly improve the system's efficiency as well as accessibility.

Flooding has also hindered all automobile traffic, and, by 2050, $95 \%$ of North- 
ern Jakarta will be submerged; therefore, all transportation networks, not just TransJakarta, will need to adapt accordingly.

Another major issue is the BRT's dedicated lanes. While most of the corridors have dedicated lanes already, there is little enforcement of the lanes themselves. Motorbikes and cars even use the lanes without any consequences. This has completely hindered the system's efficiency. Stronger enforcement of these lanes would enhance the network's efficiency and ultimately make it less convenient to drive personal vehicles. Ideally, most of the BRT's lanes would be separated to prevent a large majority of these problems from arising, but given the capital's current infrastructure state, that would be a long-term and costly goal. A shorter-term objective, to be introduced in year two of the proposed project budget, is to tightly enforce these lanes through traffic "cops" or enforcers hired by the transportation department. These enforcers would impose fines on auto and motorbike drivers who use these lanes, mostly by gathering vehicle information and sending a fine electronically. The fines would be high enough to discourage and ultimately limit these infractions. There would need to be a large number of enforcers on each route given the heavy traffic volume of TransJakarta.

\subsubsection{Moving Forward}

Looking towards the future, TransJakarta's overarching goal is to cover $70 \%$ of the people near transit in the Jakarta region, which will lead to providing service to over one million passengers daily (Ibid.). It is a major objective, but one that is very feasible with a potentially strong return on investment for infrastructure. Jakarta's first Metrorail (MRT) was unveiled this past year, and the MRT's corridor runs along a similar route as TransJakarta's first corridor line. Once again, integration is critical as some stops have already been integrated into both networks. The MRT is expected to expand to additional corridors, which will all be expected to be fully integrated with TransJakarta's network. This indicates a strong effort on the part of transportation planners to focus on multimodal forms of transportation, while also easing the major gridlock along their routes.

\subsection{Intermodal Integration}

As can be inferred from the background, Jakarta has a lot of different transportation modes and initiatives. All these initiatives can be utilized to realize the potential of all these travel modes, thus, potentially alleviating significantly the congestion in Jakarta. Currently, there is no systematic means of getting from one mode to another. Therefore, if there is such an option, more people will leave their automobiles and use public transportation, if it is feasible and well-maintained. After all, in 2002, BRT was one of the most used modes but due to issues relating to its speed and efficiency, people started turning away from it. If these problems would be solved, and there is a way to connect the modes to each other, people will use public transportation more eagerly. 


\subsubsection{Gojek and Grab as a Viable Option for Integration}

Gojek and Grab are one viable option that can be used to fill the gap that is needed to connect the different modes, especially because of how well-spread their use is in Jakarta. The effect that Gojek, for example, has on Indonesia's digital economy is huge, since it has secured around US $\$ 1.5$ billion of capital from companies such as Google and Tencent, and it contributes annually around US $\$ 705$ million to the Indonesian economy. Additionally, more than one million people are working as drivers in Indonesia alone (Urs, 2019). Therefore, Gojek (an Indonesian company also operating in Vietnam, Singapore, Thailand and the Philippines) nd its competitor Grab can be used as buffer connectors between modes due to their popularity (Gojek, 2010).

\subsubsection{Public-Private Partnership with Gojek}

To attract Gojek to such a project, a Public-Private Partnership (PPP) between the government and Gojek needs to be negotiated. Gojek has been chosen initially because it is a well-funded Indonesian company with significant foreign investment. If the PPP is successful, it can be extended to Grab. With this partnership, the government will benefit from alleviating one of Jakarta's major challenges, and Gojek will benefit by having more customers, so there is mutual benefit. One of the major outcomes of the PPP that can be expected is either updating the Gojek app or developing a new app entirely. Since the Gojek app is already popular and has a solid foundation, it would be more feasible to update it, but if the company declined due to unknown risks, a new app can be developed. The app would have the same features as Gojek, but the update would show the different routes based on convenience, speed of trip, cost or other factors. Furthermore, it would show the customer when the other mode will depart and how long the walking distance to reach the change of mode point is, if there is a distance to walk at all, so the customer can reach the mode before departure. An example of a similar app is Transit.

Another key feature that needs to be included are the places where Gojek drivers need to be in order to drop off the passengers without causing congestion on the streets, so the design of the location should be appropriate. Since the project is in its early stages, the design needs to be chosen wisely because there are a lot of stations in Jakarta. The best potential places with the most users and an appropriate street or place should be prioritized. Therefore, there needs to be research to determine the most appropriate parking area for each drop-off, and how many of these are needed. There is one more vital component, and that is using the media to spread the news of the updated app along with the newly opened stations of different modes, and how the app would help people more than before in their transportation choices.

\subsection{Citizen Engagement}

\section{Citizen Engagement in Jakarta}

Often it is assumed that planners, being university graduates and authorities in 
their field, will yield the best ideas; however, planners are sometimes so far removed the public's voice that it is difficult to hear it. The risks of disregarding the public's ideas and culture are many: the waste of funds, time and energy, damage to the government's image, underutilization of the community's greatest assets, negative consequences for the local environment, and other, unforeseen consequences. Policies need to be connected to the public and with existing policy responses. If policies are made by people who are not directly involved with the community and culture, "...responses will be seen either as inadequate to address the issue or as actually contributing to the problem." (Blomkamp et al., 2018). City plans for the urban environment must include the participation of the public and consider Jakarta's previous transportation plans.

Jakarta could become a national and global example of how governments can listen to their communities. The transportation projects and policies that are especially successful in Jakarta have the possibility to be adopted later by the Indonesian Government for other large metropolitan regions. Projects mentioned previously require new or revised policies to include a strong research phase that involves the public's voice and more data collected in order to come to an informed comprehensive conclusion.

There is a national citizen engagement program in Jakarta called the "Public Meeting for Development Planning" or Musrenbang. The Regional/Province/ National Development Planning Agency holds bottom-up meetings (village $\rightarrow$ district $\rightarrow$ city limits $\rightarrow$ greater provincial government) to increase citizen participation in the planning process. These plans take community contributions and direct them from a village level vote in March to the national level in June. These discussions with residents have the power to create positive change for the following year that are tangible, and that the community will be proud of. Through these conversations, the governments are "...able to listen to the aspirations or proposals from the community related to various aspects such as economic, socio-cultural and infrastructure....” (LintasDaerah.com, n.d.).

A Musrenbang plan for transportation in Jakarta is necessary, but it faces some major challenges. Musrenbang is an annual process during which residents meet in January to discuss the issues facing their communities and decide upon priorities for short-term improvements. Once a list of priorities is made, it is submitted to the city and the District Development Department, Bappeda, which will then assign resources to each neighborhood depending upon the available funds and according to need (Solo Kota Kita, 2020). One of these challenges, however, as The Jakarta Post states, is that Musrenbang is "quite an inefficient process." Reasons include: 1) meetings are held "on a set timeline in which citizens were required to be present, barring many working citizens from access to voice out their concerns;" 2) it is difficult to get a statistically-significant and representative sample to attend so that "the process was heavily skewed to those who had a major interest;" 3) since the budget is correlated with the size of the district, districts facing more urgent problems than others don't get more fund- 
ing accordingly.

\subsection{Conclusion}

With declining investment in transportation since the 1997 Asian Financial Crisis, Jakarta faces many issues regarding an efficient transportation network in the future. Its greatest priority is to address the immense congestion and the major gridlock that plague greater Jakarta. With five high-volume public transportation systems, the capital has the basic infrastructure in place to combat these issues. None of these respective systems has adequate connectivity to the others. As a result, TransJakarta is the critical network in this respect. The BRT's dedicated lanes need to be reinforced to improve the mobility and efficiency of the network. Integration is critical, not only between the major transit networks, but between private and personal vehicles such as motorbikes or cars. Potential partnerships between Gojek, Grab and the transportation department should be studied, and it could prove to be integral to connecting the different transportation modes. There are also far too few bike lanes in Jakarta for present demand. Research needs to continue to be conducted to make sure every rupiah is spent efficiently. As Jakarta's population rises, the citizens need to realize their own potential for making decisions and making their voices heard.

\section{Energy}

\subsection{Context and Structure of the Sector}

Jakarta is in many ways a microcosm of the remainder of the country. The capital city's energy production and potential mirror that of Indonesia as a whole, and this section includes many programs that will not just benefit Jakarta, but all of Indonesia. Following the country's economic crisis in 1998 in the wake of the Asian Financial Crisis of 1997, Indonesia saw dynamic changes in its energy sector. The government prioritized energy security through diversification of its energy resources. Jakarta's energy production today relies on a mix of five primary energy sources: crude oil, natural gas, coal, hydropower and a culmination of other renewable energy sources (Hasan et al., 2012).

State-owned enterprises (SOEs) play a key role in the Indonesian energy sector. They function as corporations but are simultaneously charged with mandates to work toward the goals and needs of the state (Ibid.). One such company is PLN, PT Perusahaan Listrik Negara. It is the only state-owned power company in Indonesia and the country's only fully integrated power utility company (Ibid.). There are other state-owned companies for the different non-renewable and renewable resources such as PT Pertamina, PT Perusahaan Gas Negara (PGN), PT Pertamina Geothermal Energy (PGE) and PT Geo Dipa Energi (GDE).

Indonesians are now becoming increasingly concerned with access to energy and electricity at the rate of a more developed country. BP reports that primary 
energy demand in Jakarta increased by $4.9 \%$ in 2018, up from the 10 -year average of $2.8 \%$ (BP, 2019). This puts ever more pressure on the power companies to provide more stable sources of power and an increasingly developed grid. As a result, most of this new power has been generated with the cheap, government subsidized resources of coal and gas. This is reflected in the $19 \%$ growth in coal production experienced nationally throughout 2018 , and the $45 \%$ incremental increase in primary power consumption supported by gas (Ibid.).

The increase in fossil fuel use is having negative environmental effects on the entire country and Jakarta specifically. In fact, Indonesia saw a $5.2 \%$ increase in total carbon emissions in 2018. In Jakarta, this growth has manifested itself in increasingly dangerous smog events. Throughout the first half of 2019, the city went through a period of particularly terrible air quality that influenced a citizen lawsuit against the government, which they hold responsible for the pollution. This increase in socio-political pressure has already led to change from the government as President Widodo recently reversed his pro-fossil-fuel stance and requested a reduction in coal use and advocated plans for more renewable energy sector development (Jong, 2019). Furthermore, in 2018, Indonesia saw a staggering $81 \%$ increase in biofuel production, demonstrating the regional demand for this source of energy (BP, 2019). The power of social change is profound, and demand for cleaner energy sources allows for a move towards renewable energy plants and green energy technology.

According to a recent report published by the National Energy Council (Dewan Energi, 2019), Indonesia is facing three major challenges to improve its energy system, infrastructure and planning. First, it is challenging to align national targets and international objectives for improvement in energy efficiency. The second major challenge is implementing clean stove technology and reducing traditional biomass consumption without creating further dependency on fossil fuels. This is especially a concern in rural areas on the outskirts of Jakarta with few alternatives and limited access to cleaner, safer technology. The third challenge facing Indonesia is the inconsistency in quantitative methods and indicators across all agencies and organizations establishing energy objectives. The primary objectives of the projects proposed here are intended to surmount these challenges.

\subsection{Proposed Projects}

The three projects proposed are Improving Energy Education, Cleaner Household Stoves, and Tapping the Geothermal Potential. While each project is effective on its own, they are most impactful if implemented collectively.

\subsubsection{Project Selection and Prioritization}

Indonesia's rank as a primary global exporter of energy products indicates its need to increase consumption of domestic energy resources, ideally renewable sources. With $40 \%$ of the world's geothermal reserves, Indonesia's greatest re- 
newable potential is just below the surface. However, the process of sourcing geothermal energy is time-intensive and costly; therefore, the project for Tapping the Geothermal Potential has the lowest priority of those proposed. It may be years before the public experiences any benefit. For this reason, small-scale sustainability interventions are also necessary to reduce quickly non-renewable consumption. Given that most households rely on coal- and wood-burning stoves for fuel, the Cleaner Household Stoves project is the most direct and effective method of small-scale intervention. The lack of data, education and support for renewable energy highlights the socio-cultural shift necessary to ensure the success of these proposed projects and of any sustainability-related intervention. Education-and the grassroots support it garners-is the most important aspect to address as it is critical to the success of all other projects. For this reason, the Improving Energy Education project is given the highest priority.

\subsubsection{Improving Energy Education}

This is a short-term project that is easily implemented and can be completed over a relatively short period of time. Partnerships are an important aspect of improving energy education. A partnership with commercial banks to educate them on the benefits of renewable energy sends a clear message to a broad audience that renewable energy will receive long-term, stable policy support. Having fiscal support for the financing of renewable energy projects is the largest barrier to geothermal exploration and energy growth. Educating banks on the long term returns possible within this sector could garner a great deal of support.

On a larger scale, this program is focused on spreading awareness to the general population of Jakarta about the benefits of adopting a cleaner energy mix. The residents of the city are already seeing the negative effects of their coal-powered plants in the poor air quality they experience. This is raising a great deal of awareness before any further outreach, but there is a great opportunity to tap into this crisis and share a different way moving forward. For this, most of the improving energy education budget is allocated to a social media campaign. Social media is an effective way to reach a wide variety of Jakarta residents and present them tangible data about their city's energy production mix and the effects that is having on them. For example, effective infographics can share information about Indonesian geothermal energy potential and even how this energy works in general. Spreading graphics such as these around prominent social media pages will educate a large number of Indonesians about the pros and cons of renewable energy vs. non-renewable energy and, hopefully, garner a great deal of grassroots support for advanced energy practices. The result of this program is, hopefully, to influence local and national governments to work actively to implement renewable energy programs and prioritize removing non-renewable fossil fuel subsidies.

\subsubsection{Cleaner Household Stoves}

In Indonesia, households using traditional, inefficient stoves typically burn bio- 
mass that emits health-damaging pollutants into household environments, most directly affecting women and children. Since the 1970s, various groups have tried to introduce cleaner cooking technology in Indonesia, but their efforts lacked consistent funding and institutional support.

This medium-term project involves the conversion of biomass stoves into cleaner and more efficient biogas stoves. An example of this type of stove is shown above in Figure 9. Many households have been shifting to modern cooking fuels and technology, but about $40 \%$ of households still rely on traditional biomass material (mainly wood) for cooking (Apex Consulting Group, 2013). This translates to about 24.5 million households throughout all of Indonesia. One of the main reasons for promoting clean stove technology is because the current method of cooking with biomass stoves produces unhealthy indoor pollution.

Indonesia has high potential for biofuel, particularly given the country's status as the largest producer of palm oil (Tharakan, 2015). Increasing, the use of biogas produced from palm oil mill effluent is cost-competitive, and it avoids the methane emissions produced by unused biogas (IRENA, 2017).

A pilot project for cleaner stove technology has already been initiated, but the locations of its efforts have been in Central Java, as well as on another island to the east of Java (Apex Consulting Group, 2013). Therefore, the project proposed here aims to build on this initiative, but instead focus on Jakarta. The Cleaner Households Stoves Project involves training workers to convert coal- and wood-burning stoves into biogas-based stoves. These trained workers are also needed to install the new stoves, as well as to train the families on how to use the new technology.

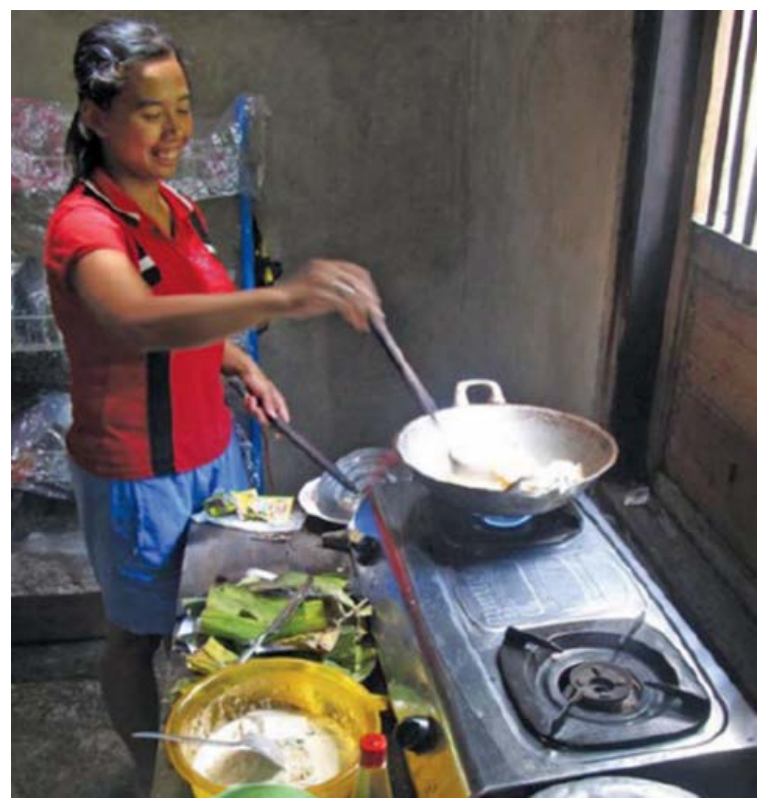

Figure 9. A woman cooking on a new biogas stove. Source: Zhang et al. (2003), Indonesia-Toward Universal Access to Clean Cooking, 2013. 
The increased prevalence of household stoves also leads to an increased need for biogas generation. As a result, this project partners with the Indonesian company, Hivos, which is trying to create a market-oriented sector of domestic biogas business opportunities. It trains residents to become skilled masons who construct biogas digesters and sell them at an affordable price to neighbors. This method is the perfect way to create a sustainable biogas sector within Indonesia that will last and increase social equity (Hivos, 2017).

\subsubsection{Tapping Geothermal Potential}

This is a long-term project that requires at least six years of implementation to be fully operational. Geothermal power plant projects require high upfront investment due to the various studies and exploration needed in order to find a viable active geothermal source. Geothermal energy has attractive operating costs, given that the renewable resource is freely available in the ground. However, the high exploration and construction costs make geothermal energy a risky investment, and private companies are reluctant to develop it. Moreover, as it takes five to seven years to begin operations, revenues are slow to materialize (Fan \& Nam, 2018). Additionally, geothermal exploration comes with a high risk due to the lack of clear data about geothermal sources in Indonesia.

In order to locate a strong source of geothermal energy, a preliminary survey, exploration/test drilling, a feasibility study, and a planned pilot project are all required. For the preliminary resource identification phase, the selection of the field is carried out, and this selection is based on the presence of geysers and/or evidence of volcanic activity (Gudmundsson, 2016). The surface exploration and exploration drilling phase involve thorough geological, geophysical and geochemical exploration in the field (Ibid.). During this time, some shallow drilling is typically carried out. Exploration drilling involves drilling a few exploration wells to confirm the resource potential. This part is very risky, and, as a result, it is often challenging to fund (Ibid.).

This proposed geothermal plant project aims to expand the geothermal data in the region around Jakarta to create a basis of information for future geothermal plants. The hope is that by establishing a database with geological data, the costs of building future geothermal plants can be reduced as the need for preliminary studies, exploration drilling and feasibility studies will no longer be needed.

\section{Water}

\subsection{Background}

Jakarta is one of the most densely populated cities in the world (Chaudhuri, 2018). However, many water amenities such as new water connections, water wells and more are too expensive and unaffordable to millions of low-income families (water.org, n.d.). In addition, Jakarta has an extensive system of canals and seawalls, as the city is a coastal city that is located along Jakarta Bay in the Java Sea. 
As a coastal city, Jakarta also faces many of the challenges and problems that other coastal cities around the world must deal with, i.e., flooding and sinking. These problems can be traced back in many ways to climate change (Simon, 2019). However, when considering as well the increased urbanization and population growth that affect Jakarta and many other density populated cities, it is clear that this also leads to the inability of large areas to absorb rainfall due to ever increasing impermeable surfaces (Chaudhuri, 2018).

The city's subsidence, though partly due to climate change, is a consequence of groundwater extraction that is taking place throughout the vast urban agglomeration of Jabodetabek, with its 30 million inhabitants, and Jakarta at its center. Groundwater extraction is one of the cheapest ways for people to get access to clean water, so residents and industries have been extracting from and draining aquifers, often illegally, to the point where the city has sunk well below sea level. Models predict that by 2050, 95\% of North Jakarta could be submerged (Simon, 2019). In fact, Jakarta is reportedly the fastest sinking city in the world (Rosane, 2019).

Approximately $75 \%$ of the citizens of Jakarta rely on groundwater, even though there are studies that show $90 \%$ of the water is contaminated with bacteria. Only around $50 \%$ of the city's population has access to clean piped water, while the others, mostly low-income households, do not have clean water access, so they wash their clothes and bathe in murky grey water. This leads many of these lower income households to spend money, not only on clean water from vendors, but to gain access to water through extracting groundwater and by other methods (Ann, 2015).

Moreover, along with land subsidence and sea level rise, existing elevation, high rainfall and low drainage capacity all together make Jakarta one of the highest flood risk cities in the world (Garschagen, Surtiari, \& Harb, 2018). About $40 \%$ of Jakarta's area, especially in North Jakarta, is below sea level (Luo, et al., 2019).

\subsection{Solution}

For Jakarta, there is no single solution to the water related problems, and, as the problems are interrelated, solutions should be interrelated. Some problems seem to be wicked, i.e., if a solution is adopted, it might be solved by creating another problem. For example, rapid urbanization/development is one of the critical causes of land subsidence, but, to reduce the rate of land subsidence, it is assumed that the Indonesian Government would not adopt a policy to control urbanization because it would substantially reduce the economic growth of the country.

\subsubsection{Government Efforts}

1) Capital Relocation

All the water related risks discussed here, along with other issues facing a ra- 
pidly growing metropolis and capital city of a developing country of Southeast Asia, have influenced the Indonesian Government to accept the escape policy of Capital Relocation. On 27 August 2019, Kate Lyons of The Guardian (Lyons, 2019) reported that President Joko Widodo announced that the national capital will move from Jakarta, on the island of Java, to the province of East Kalimantan, on Borneo. What is critical to remember, however, is that Capital Relocation will not solve all the problems of Jakarta, especially its water problems. It might slow the rate of land subsidence, but there will still be subsidence, and the sea level will continue to rise. It might reduce the gap between the supply and demand of drinking water, but a gap will nevertheless remain (Figure 10).

\section{2) Giant Sea Wall}

The Indonesian Government adopted the National Capital Integrated Coastal Development Masterplan (NCICD) in 2014, which was an expansion of the Jakarta Coastal Defense Strategy. The main idea of the plan is to construct a "giant sea wall" (also known as the Great Garuda Project) to block Jakarta Bay from the sea. The project has already been designed by a consortium of Dutch and Indonesian planning consultancies, sponsored mainly by the Dutch Government. It would consist of a $25 \mathrm{~km}$ long sea dyke, and a bay enclosed by the dyke would be converted into a water reservoir, which would be below sea level due to extensive water pumping from the reservoir into the sea. In addition, the plan also includes upgrading and expanding existing flood protection measures like retention reservoirs, drainage canals, coastal dams, etc. Within the reservoir, the project includes massive land reclamation for a new $\mathrm{CBD}$ and residential area, with a new harbor and airport to attract an additional 650,000 people and provide 350,000 jobs.

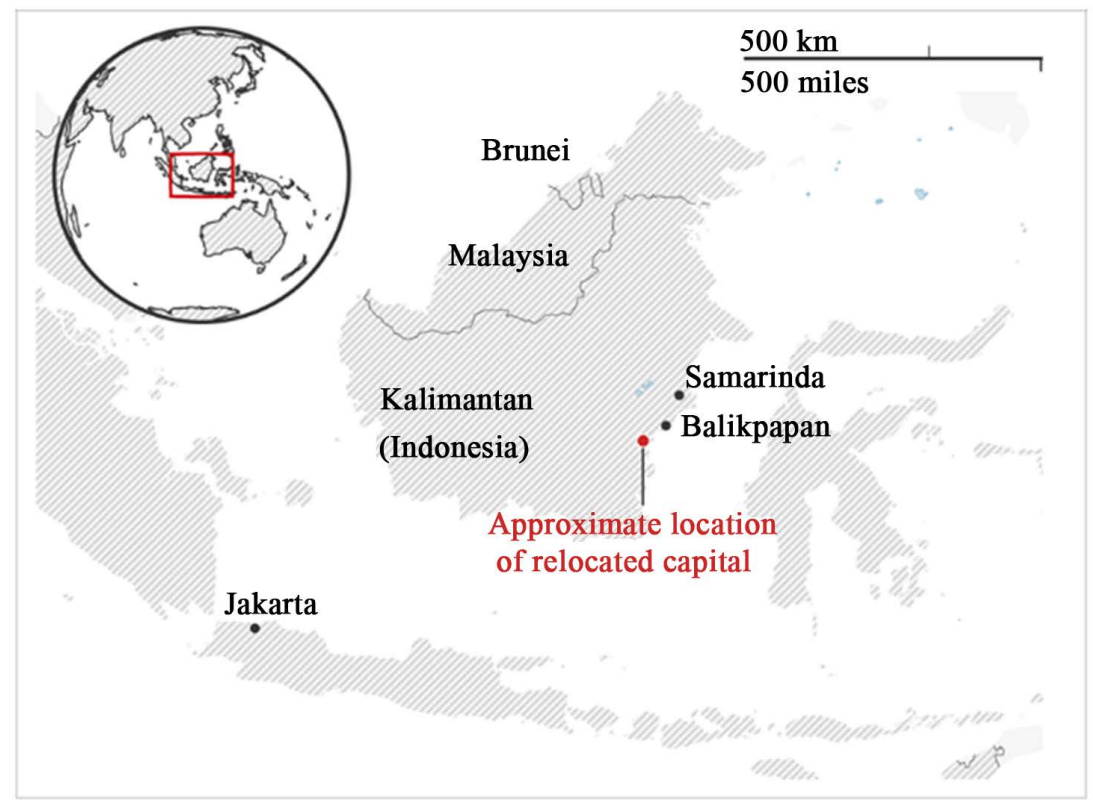

Figure 10. Map of Indonesia's capital relocation. Source: Lyons, 2019. 
Although the Government of Indonesia is confident about this ambitious US $\$ 40$ billion, 30-year project, many Indonesians, especially in the coastal region of Jakarta, are concerned about the negative impacts of the project. The embankment might cause severe environmental degradation, including damage to local fisheries.

\subsubsection{Proposal}

A comprehensive approach is needed to solve the water problems of Jakarta. As was discussed earlier, the problems are interrelated, and it is necessary to identify the causes and effects of the problems. It is evident that the solution of one problem might solve other problems and, in many cases, it is also true that it might create new problems or intensify other problems instead of solving them.

The three major problems related to water in Jakarta are sinking/flooding, water pollution and scarcity of water supply/drinking water. As the problems are interconnected, if the problem of drinking water/water supply can be solved using surface water, or some other alternative source(s) of water other than ground water, it will reduce significantly ground water abstraction. As a result, land subsidence would be slower, which could be a significant improvement for solving the sinking/flooding problem.

It is assumed that even after Capital Relocation, Jakarta's growth will continue, but at a slower rate, so problems with water will continue in the future. It would, therefore, be wise to think of alternative sources of water. Since Jakarta has an average annual precipitation of $1755 \mathrm{~mm}$ (climatemps.com, n.d.) rainwater harvesting could be a good option for an alternative source of water. Grey water recycling could be another alternative source of water, which could save up to $70 \%$ of domestic water use.

\section{1) Rainwater Harvesting}

There are different statistics about how much water demand is satisfied by the supply of water from utility companies in Jakarta. For example, one study finds the figure to be $60.6 \%$ (Sari \& Suhendri 2018), while another asserts it is around $40 \%$ (The World Bank, 2017). Whichever is correct, it is obvious that there is a very large gap between supply and demand. Rainwater harvesting could significantly supplement supply. Theoretically, it is possible to collect almost $100 \%$ of the need if all the households in Jakarta could catch all of their rooftop water (Sari \& Suhendri, 2018). So, rainwater harvesting, a simple technology and comparatively cheap to install and operate, offers the possibility to bring revolutionary change to the water crisis of Jakarta if it is successfully installed and operated throughout all suitable areas of the city. While an individual system might not be a problem in rural Indonesia where houses are separate from one another, in Jakarta, it is preferable to install communal systems based on clusters of houses, especially in low income areas. Therefore, it is proposed that in the 5 -year duration foreseen for the environmental plan for Jakarta that 73 communal systems be installed, which could later be scaled up. 


\section{2) Grey Water Recycling}

Grey water, constituting $50 \%$ to $80 \%$ of total household wastewater, represents the largest part of the wastewater from households, offices and schools (Firdayati et al., 2015). Much like rainwater harvesting, grey water recycling could be a potential cheap source of alternative water in Jakarta. It can significantly supplement the existing water supply and dramatically reduce the wastewater discharged into rivers by a large amount.

For grey water recycling, a simple system is proposed, which will produce water that can be used for all household activities except drinking. There are a number of reasons behind this; first, a separate small filter can be used for drinking water, so there is no logic to make all water drinkable using expensive technology as drinking water makes up less than $5 \%$ of total domestic need; second, simple recycling is cheap and easy to maintain; third, people's perception might be negative about drinking recycled water directly.

For the pilot project, ten systems could be installed in the three places previously chosen for rainwater harvesting systems, but this time the households should be different so that both systems can be judged separately. The reason behind choosing the same neighborhoods is that it would be easier to monitor both systems by the implementing authority. If the pilot succeeds, 30, 50, 100 and 100 systems could be installed in the second, third, fourth and fifth years respectively. As the maintenance cost is negligible, it would be borne by the users of the systems.

\subsection{Conclusion}

As presented here, one can see that there is no easy fix for the water crisis that Jakarta is facing. The problems surrounding water have been ignored and left unchecked for too long, and the government decided that it would easier to just pack up and create a new capital city, as well as implement gigantic projects, such as the updated seawall, that will cost billions of dollars and take years to complete. Instead, the proposed projects in this section are directed to help the current residents in the city who presently have limited or no access to clean water. These projects are simple and cheap, but very effective, and they could help provide clean water access to all 10 million residents of Jakarta.

\section{Sewage and Sanitation}

\subsection{Background}

The city of Jakarta is facing an issue that afflicts many developing countries, that of proper sewerage and sanitation services. Bacterial infections, such as E. coli, run rampant and cause approximately 50,000 deaths in Indonesia annually (IRIN News, 2015), while waterways are filled with trash and blackwater from pollutants. The unsuitable management of sewage and sanitation poses a serious health threat to the millions of people that call the city home. 
Much of the sewage management within Jakarta is privatized due to the absence of a comprehensive city-wide sewage system. Most residents own a septic tank system, which only focuses on collecting sewage from that property. These systems require regular maintenance for properly emptying and disposing of waste and can and, often do, overflow. While there are some small-scale communal sewage treatment facilities in neighborhoods, there are not nearly enough to deal with the local need. The city of Jakarta, and Indonesia as a whole, has tried to establish solutions to this problem, one of which was to create a citywide sewage system costing upwards of US $\$ 4$ billion. The cost to develop the system is relatively reasonable; however, having to tamper with and/or remove the existing underground infrastructure is extremely expensive, which is why this system has been delayed for well over a decade. Along with this, there is also the issue of convincing residents to help pay for the service. Most residents would rather use their own private system and hire cheap labor to remove the sewage, regardless of whether if, after it is removed, there is proper disposal.

The sanitation issue falls under the proper management of human generated solid waste and its impact on the health of natural resources. The images that are typically associated with Jakarta are the rivers filled with plastic bags, bottles, containers, clothing and paper products. These items seem to always find their way into a body of water, a landfill mountain, or onto factory floors close to active fires. There is both a lack of a proper method to dispose of trash, as well as the inadequate knowledge of residents on how to make changes to do so, as this has become an accustomed way of life.

The city's sewage and sanitation dilemmas follow the same pattern as in many other developing countries. There have been efforts made through various programs to alleviate the problems, but none have made a substantial enough difference or have the required reach. This section proposes various projects that can begin a pattern of success in this regard for the people of Jakarta.

\subsection{Proposed Projects}

\subsubsection{Large Scale Sludge Removal Carts}

This concept is one that is already in play at a small scale in Jakarta. The issue with many septic tanks is that they are not accessible via sludge trucks, as the tanks are too large to navigate the narrow streets of low-income neighborhoods. It began as the PUSH project created by the Mercy Corps, which was a preliminary study phase, from which the RW Siaga Plus was developed, which designed the carts and funding mechanism. Funded by Coca Cola and USAID and coordinated with the local Ministry of Health, the project has created access for more than 9000 individuals and 1800 households. It has also encouraged district health offices to educate their communities (Oliver, 2012) (Figure 11).

The project proposed here is to use government funding, as well as loans or grants from countries that want to invest in sanitation management, to expand this program. If it were available on a larger scale, it could greatly reduce 


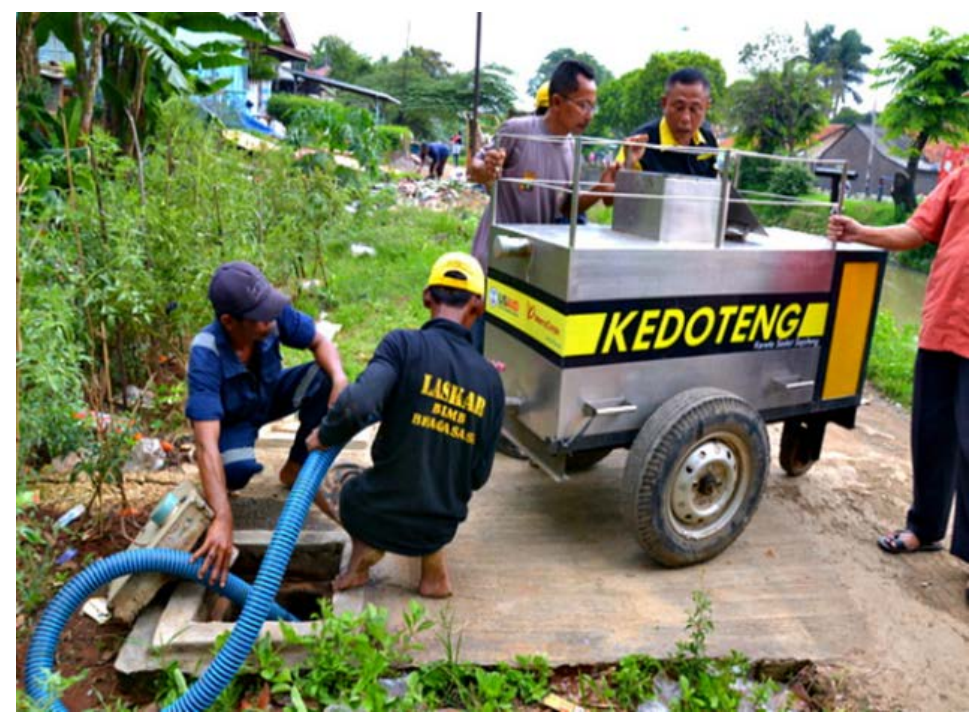

Figure 11. Three-wheeled sludge cart. Source: Dillian, 2012.

wastewater being leaked into groundwater or dumped illegally, as well as improve the overall health of residents. Ideally, the government would work together with a manufacturer to create the carts, securing them at a fair price, and the government would sell them to private operators by issuing small business loans and also mandating that sludge be disposed of at proper waste disposal sites.

\subsubsection{Communal, Neighborhood Scale Wastewater Treatment Systems}

The city of Jakarta has attempted to create a large-scale sewage system that would serve large portions of the population. However, this idea has been delayed for over a decade due to the cost of disrupting existing infrastructure. While the idea to use sludge carts could aid in resolving parts of this issue over time, there exists the problem of removing the human waste and making the water safe enough to be discharged back into the environment. The neighborhood of Malkaskai, is one of the few that has found a solution to this issue by having a communal, small scale, wastewater filtration system. It uses a system that allows 500 households to dispose of wastewater properly and have it cleaned to a point of being able to be released back into waterways with less pollution; it is known as grey water (The Jakarta Post, 2015b). A system of anaerobic and aerobic digesters is used to clean the water, and each has a different process as well as implementation cost, but is relatively affordable in comparison to the large-scale system Jakarta has been attempting to implement over the past decade.

Both systems have their strengths and weaknesses, but still offer the same result of diluting blackwater sewage into a safer form of grey water. This grey water can then be released back into the environment, allowing natural processes to finish the purification as it seeps back into the water table. This process then allows the water to return to underground aquifers, allowing for underground wells to be recharged over a span of time. 


\subsubsection{Promoting Environmental Protection Awareness Program}

While there are environmental laws in place, such as Waste Law No. 18/2008, they do not produce the expected effect, due to most citizens in the developing country being more concerned with personal income than environmental issues, and they are difficult to enforce by the government. This new program will increase awareness of the growing solid waste problem by first designing an environmental curriculum for elementary schools. Countless studies have shown that children are better able to accept new knowledge and build a new behavioral model. There would also be homework assignments given to complete with students' parents, hence promoting environmental awareness through children. An environmental poster printed by the local government will be given to every community, similar to the ongoing local government trash sorting campaign.

\subsubsection{Improving Community Based Recycling Systems}

The current recycling system, Trash Bank, is a relatively inefficient system as it takes trash per individual, which is a slow process. This project would be an upgraded system with each community having a series of marked garbage bins to allow the self-service recycling of materials (Figure 12).

After self-assisted or manual weighing, citizens put waste in the corresponding recycle bin. The value is then calculated and sent to their own account after the collection of the trash. This project will also incorporate social media apps, allowing users to see real-time deposits in their accounts from recycling, stimulating users to improve their initiative. At the same time, a reward system can be implemented for communities with higher recycling rates and increase the recycling intention of surrounding communities (jpninfo.com, n.d.).

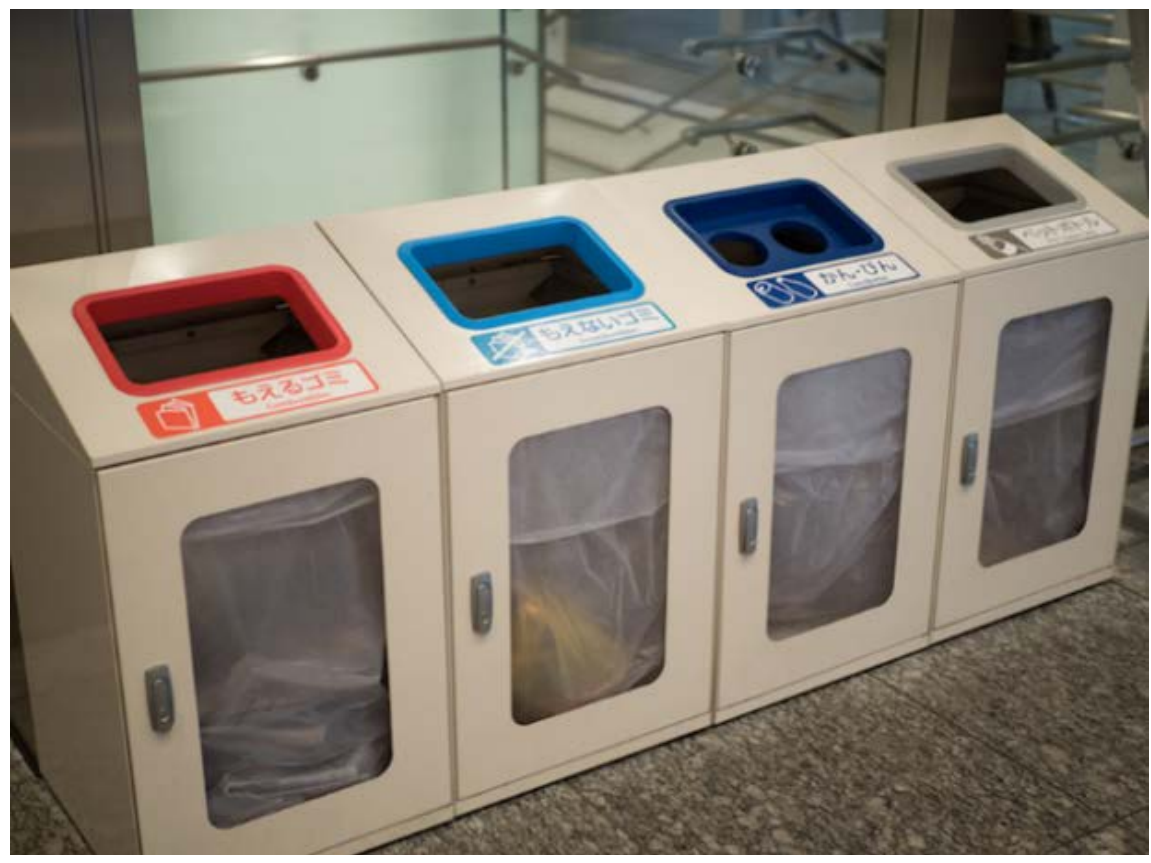

Figure 12. Trash separator trash cans. Source: jpninfo.com, n.d. 


\subsubsection{Improving the Treatment Infrastructure}

According to the List of Cities Screened for Support under the Government of Indonesia's The Improvement of Solid Waste Management to Support Regional and Metropolitan Cities Plan (ISWMP), all of Jakarta's landfills will reach capacity by 2025. This project will establish new final disposal sites, located far from the central district, with new sanitary landfill technologies. Some of these technologies may be leachate treatment facilities, anaerobic digesters and mechanical biological treatment (MBT). Along with this will be the redevelopment of existing final disposal sites that will be converted to the newer more efficient technology systems (Ibid).

\subsection{A Clean Conclusion}

With the problems facing Jakarta in sewage and sanitation, there is a need to find viable and practical solutions, i.e., solutions that can solve these problems without disrupting the existing infrastructure, which has been one of the most significant factors in the failure of many of the city's proposed projects in the past.

The push to utilize sludge carts could serve as an alternative to creating a pipe-based system and be a good starting point for serving many residents in a short period of time. As a secondary development, the creation of communal sewage systems would reduce the amount of blackwater being discharged into the environment and allow grey water to be purified naturally and eventually filtered back into the water table.

Educating residents on the need for proper solid waste disposal and recycling and the creation of proper disposal methods can lead to a drastic reduction in waste in the environment. Providing residents with incentives through a rewards program could help push for a more effective separation of waste, as well as increase community involvement and generate a sense of pride, while also encouraging the use of new ways to manage this waste so that it doesn't end up polluting the environment and seeping into living spaces.

The purpose of this section has been to highlight the current problems facing Jakarta in terms of its sewage and sanitation. The city does want to resolve these issues, but it lacks the practical creation and management skills needed. Moreover, the existing built environment is a major obstacle to development. Using smaller scale projects that have little effect on the existing built infrastructure could be the key to solving these issues, allowing for the city to develop more reliable ways to dispose of sewage and solid waste so that Jakarta can become a safe and sanitary place for everyone to live.

\section{Finance}

\subsection{Introduction to Finance in Jakarta}

Indonesia is the world's fourth most populous nation, and the world's tenth largest economy in terms of purchasing power parity. The nation has had im- 
pressive economic growth since overcoming the Asian Financial Crisis of the late 1990s. The country's GDP per capita has steadily risen, from US \$823 in 2000 to US $\$ 3932$ in 2018 (The World Bank, 2019). Despite having this substantial growth, poverty remains a serious problem. Indonesia currently has a GNI per capita of US \$2611, more than 120 million Indonesians (over half of the population) live on less than US $\$ 2$ a day (Dugay, 2012). That said, Jakarta, Indonesia is the center of roughly one-fourth of Indonesia's trade and services and two-thirds of its banking and financial sectors.

The objective of the finance section of this project to develop an environmental plan for Jakarta has been to research and examine the internal and external sources of funding for Indonesia in general, but for Jakarta in particular. Sources of this revenue include the overall government budget, foreign direct investment and foreign aid. From that, it was determined how much funding was potentially available for the proposed projects in the city. Each of the sector teams for poverty alleviation, industry, transportation, energy, water, and sewage and solid waste proposed their list of potential projects and estimated how much funding Jakarta would need for the projects to be implemented successfully over the 5 -year planning period. The finance team then determined the money that would be available for each potential project by looking at the amount allocated to each sector through the three sources of funding mentioned above.

\subsection{Government Budget}

In approaching the amount of funds available from this source, the proposed budget report of the Department of Budget and Management for 2019 for Jakarta was analyzed. When planning a project in Jakarta, one must recognize that the city has over 70 program categories that separate different budget categories for each fiscal year. Each of those categories has a specified amount of money allocated to be spent annually. That said, many of the program categories relate to each other, and can essentially be combined into one simple spending category. For instance, numerous categories relate to education in some way. When combining the budgets for those categories, the general category of "Education" is roughly $25 \%$ of the 2019 budget, and a major focus for funding projects moving forward. In addition, the 5-year performance indicator, also known as the Rencana Pembangunan Jangka Menengah Nasional (RPJMN), indicates that there is a major focus on solid waste management, flood mitigation and fire prevention. The reason the RPJMN may focus so much on these areas is because seasonal flooding has been a part of life in Jakarta since the seventeenth century. Fires typically receive a significant amount of the annual budget, and these disasters lead to problems with solid waste. Nevertheless, a proposal may be to take a small percentage from another budget (like Education) and add it to the "Public Works and Spatial Planning" category, which focuses on the RPJMN priorities mentioned above. The Public Works and Spatial Planning category accounts for roughly $12 \%$ of the 2019 budget, but next year may need $13 \%$ or $14 \%$ to account 
for these issues moving forward.

Considering the government budget, Jakarta has yearly goals for how it operates. These goals include the Human Development Index, poverty rate, investment spending, and much more. This list gives a rough idea of what the government wants to achieve for the 2020 fiscal year. One key takeaway from the list is the fact that it intends to allocate over US $\$ 7$ billion to investment spending. This amount, then, indicates the availability of funds to the city for that fiscal year. As mentioned previously, out of that US \$7 billion, the RPJMN-based focus could lead to more funds being spent on waste management, flood mitigation and fire prevention, rather than on education, health and some of the other top categories

\subsection{Foreign Direct Investment}

Foreign direct investment (FDI) entails the investment of private companies from different nations in private companies in Jakarta, and Indonesia in general. These different firms typically invest to manufacture products and generate a worthwhile profit for the investors. Consequently, it was determined which countries' companies provide the most foreign direct investment, and what share of overall investment poured into the city. For the first half of 2019, Singapore companies invested the most money in Indonesia with US \$3.4 billion for over 5000 total projects. Following Singapore, was Japan, whose firms invested over US $\$ 2.4$ billion for over 3700 , then China at US $\$ 2.3$ billion, Hong Kong at US $\$ 1.3$ billion, and Malaysia at US $\$ 1$ billion (The Jakarta Post, 2019b). Overall, total foreign direct investment stood at US $\$ 28.2$ billion for Indonesia during the first half of 2019, which was an increase of $9.4 \%$ from the same period in the previous year.

When assessing in what sectors each country invests, one must acknowledge that there are similarities and differences between these nations. Singapore, the largest investor in the first half of 2019, focused on investing in education, culture, defense and the environment (Ministry of Foreign Affairs of Singapore, 2019). In contrast, the second highest investor, Japan, typically invests in finance and technology for the nation.

So how does foreign direct investment benefit Indonesia, and Jakarta? Overall, Jakarta's government must look at its government budget line for each category, and also look at its RPJMN (5-year priority investment plan), to note what countries are investing in categories that best align with its future plans. For instance, as mentioned, Jakarta annually allocates roughly $25 \%$ of its overall budget to education. When nearly one fourth of the city's entire budget is allocated to an individual category, a lot of potential funds for other needs are eliminated. Thus, Jakarta and Indonesia can benefit from the investment that lines up with their priority categories. Nations like Singapore, The Netherlands, and even the United States, directly invest hundreds of thousands of US dollars in Indonesian education. Even though investment requires a profit for the original investors 
from a nation, it still helps with funding and producing the product in general (schools, books, educational technology, etc.). The investment and construction of a new school in Jakarta from Singapore may not bring in an abundance of profit for Jakarta itself, but it may give the city the opportunity to reallocate funds towards their 5-year Rencana Pembangunan Jangka Menengah Nasional (RPJMN), which places emphasis on solid waste management, flood mitigation and fire prevention.

\subsection{Foreign Aid}

Foreign aid is the international transfer of capital goods or services from a country or international organization for the benefit of a recipient country or its population (Due et al., 2018). Foreign aid can involve the transfer of various commodities, such as food and military equipment, or different assistance, such as technical advice and training. Countries also provide foreign aid to combat natural or man-made disasters, such as famine, disease and war, to promote economic development, to help establish or strengthen political institutions, and to address a variety of transnational problems, including disease, terrorism and other crimes, and destruction of the environment. In addition, this transfer of services comes in various forms, such as bilateral aid from individual countries, including grants and concessional loans. The main difference between the two is that grants do not have to be paid back, but concessional loans are loans offered at interest rates below those available on the market, or loans with grace periods, or a combination of these. Concessional loans typically have long grace periods (OECD Statistics Directorate, 2003).

Specifically, Indonesia as a nation receives plenty of foreign aid from many different entities. Some of the top institutions giving the most to Indonesia are the Asian Development Bank, The World Bank, the Global Fund to Fight AIDS, the United Nations and the Millennium Challenge Corporation. In addition, some of the bilateral donors that give foreign aid to Indonesia are the German Federal Ministry of Economic Corporation and Development (BMZ) the Japan International Cooperation Agency (JICA), the Australian Agency for International Development (AusAID, Agence Française de Development (AFD), and the United States Agency for International Development (USAID).

Overall, when looking at foreign aid, one must recognize the difference between it and foreign direct investment. Essentially, foreign direct investment refers to a source from another nation putting funds into Indonesia with the expectation it gets a return on that investment. As mentioned above, foreign direct investment can benefit Indonesia, and Jakarta especially, in terms of private sector projects. However, foreign aid that is sent to Indonesia is used to benefit Indonesia's people directly. If The World Bank allocates millions of dollars of foreign aid to Indonesia for the construction of a new school, with new books, equipment, etc., then Indonesia reaps direct benefits for those who attend the school and indirect benefits for the country through the additional productivity 
of the school's graduates.

\subsection{Conclusion}

Financing various projects in Jakarta may require much more than the funds in the Government of Indonesia budget. While the budget includes the amount of money allocated for each government sector, it does not fully fund every potential project in those sectors. Thus, sources of foreign direct investment and assistance provided by foreign aid enable the government budget to have some leeway and allow opportunities to spend more for potential projects in Jakarta. As a result, the 2020 Government Performance Agreement (Perjanjian Kinerja, 2019) allocates over US $\$ 7$ billion in investment spending for the year. With many different sources of aid and investment helping to reach this goal, numerous projects will likely be created in Jakarta.

Therefore, based on the above analysis, the finance team concludes that the three sources of funding available, i.e., the Indonesian Government budget, foreign aid and direct foreign investment, provide enough money to fund each proposed project from the poverty alleviation, industry, transportation, energy, water, and sewage and sanitation sectoral teams.

\section{Final Comments}

The intent of this project was to bring the contemporary thinking and practice of Urban Environmental Management to the solution of real problems in Jakarta, Indonesia, the largest city in Southeast Asia and the heart of the second largest urban agglomeration in the world. The objective was to replicate as much as possible the conditions under which a team of expatriate consultants would operate in this context so that they could develop ideas and procedures that fitted the circumstances they would likely confront as professional planners working on such projects for international development banks, multilateral donors in the United Nations system, as well as the numerous bilateral donors of the developed countries.

In this working environment, it was instructive for the students to formulate a 5 -year plan of solutions to the environmental problems and issues they faced rather than be told how to deal with them. This expanded their analytical skills and taught them how to utilize the limited knowledge and resources available to come up with implementable solutions for the benefit of the people of Jakarta. They learned that such skills were transferable to other projects, and they gained a greater appreciation of the skill set that they were developing as planners (Edelman, 2016). Bringing the reality of development to the classroom and asking the students to confront it gives them an appreciation of professional practice that the study of theory alone does not. Consequently, this project has attempted not only to expand the education of graduate students, but also to provide a meaningful contribution to planning pedagogy (Edelman, 2015).

Of course, the project has been limited by the students' inability to be on site 
in Jakarta. However, this was mitigated somewhat by the instructor's professional experience in Indonesia as well as the presence of two Indonesians in class. One had five years of government planning experience and both assisted the instructor with guiding the participants through the government structure and practices, as well as the mass of data written in Bahasa Indonesia.

This study is the sixth in a series of studies that focus on the practice of Urban Environmental Management (UEM) in developing countries which face more immediate, critical problems than the developed world and have fewer resources to deal with them in a comprehensive manner. Previous studies have proposed environmental plans for Mysore, India (Edelman, 2014), Lagos, Nigeria (Edelman, 2015), Manila, The Philippines (Edelman, 2016), Lima, Peru (Edelman, 2018) and Santo Domingo, The Dominican Republic (Edelman, 2019). Future books are planned for Istanbul, Turkey; Kingston, Jamaica; Nairobi, Kenya; Casablanca, Morocco, and San Juan, Puerto Rico. In the wake of the HABITAT III Conference in Quito, Ecuador in 2016, these studies contribute directly to understanding the urban environmental challenges inherent in achieving the objectives of the conference's final document: The Quito Declaration on Sustainable Cities and Human Settlements for All (HABITAT, 2016).

In a rapidly urbanizing world, the $21^{\text {st }}$ century is considered the urban century with international debates and reflection on cities across a range of political arenas and policy agendas. But while cities and urban regions are the key sites of economic and social progress in the $21^{\text {st }}$ century, they also face many challenges surrounding social equity and environmental pressure. This project has served to highlight these issues in one of the world's largest cities.

\section{Conflicts of Interest}

The authors declare no conflicts of interest regarding the publication of this paper.

\section{References}

Aisyah, R. (20 January 2019). Indonesia's Services Sector Has Great Potential, Trade Ministry Says. The Jakarta Post.

https://www.thejakartapost.com/news/2019/01/20/indonesias-services-sector-has-great -potential-trade-ministry-says.html

Ann, C. (3 April 2015). Your Letters: Clean Water Problem in Jakarta. The Jakarta Post. https://www.thejakartapost.com/news/2015/03/04/your-letters-clean-water-problem-ja karta.html

Apex Consulting Group (2013). The Case for Clean Biomass Cookstoves in Indonesia. http://ApexConsultingGroup.com/the-case-for-clean-biomass-cookstoves-in-indonesia/

Arbi, I. A. (4 January 2019). Indonesia Focuses on Polytechnics amid Staggering Skills Gap. The Jakarta Post. https://www.thejakartapost.com/news/2019/01/04/indonesia-focuses-on-polytechnicsamid-staggering-skills-gap.html

Asia Link Business (n.d.). Indonesia’s Economy. 
https://asialinkbusiness.com.au/indonesia/getting-started-in-indonesia/indonesias-eco nomy?doNothing=1

Asian Development Bank (2019). Policies to Support the Development of Indonesia's Manufacturing Sector during 2020-2024. A Joint ADB-BAPPENAS Report, Manila: Asian Development Bank.

Australian Government Department of Foreign Affairs and Trade (August 2019). Indonesia. Australia Department of Foreign Affairs Countries, Economies and Regions. https://dfat.gov.au/trade/resources/Documents/indo.pdf

Badan Koordinasi Penanaman Modal (BKPM) (2019). Making Indonesia 4.0: Indonesia's Strategy to Enter the 4th Generation of Industry Revolution.

https://www2.investindonesia.go.id/en/why-invest/indonesia-economic-update/makin g-indonesia-4.0-indonesias-strategy-to-enter-the-4th-generation-of-ind

Badan Pusat Statistik Provinsi DKI Jakarta (BPS DKI Jakarta) (2019). Gini Ratio 2017-2018. https://jakarta.bps.go.id/subject/155/gini-rasio.html\#subjekViewTab3

Blomkamp, E., Sholkin, N. M., Lewis, J., \& Toumbourou, T. (6 February 2018). Understanding Policymaking in Indonesia: In Search of a Policy Cycle.

https://www.ksi-indonesia.org/file upload/Understanding-Policy-Making-in-Indonesi a-in-Searc-06Feb2018141656.pdf

BP (2019). Indonesia's Energy Market in 2019. BP Statistical Review.

BPS (2016). Statistik Indonesia 2016. Jakarta: Badan Pusat Statistik.

Brown, A. (15 February 2013). The Dark of Day: Life in a Jakarta Urban Slum. UNICEF Connect East Asia and Pacific.

https://blogs.unicef.org/east-asia-pacific/the-dark-of-day-life-in-jakarta-urban/

Business Sweden (2018). Indonesian Priorities in Making Indonesia 4.0.

Caljouw, M., Nas, P., \& Pratiwo (2005). Flooding in Jakarta: Towards a Blue City with Improved Water Management. Bijdragen tot de taal-, land-en volkenkunde/Journal of the Humanities and Social Sciences of Southeast Asia, 161, 454-484. https://doi.org/10.1163/22134379-90003704

Chaudhuri, E. (22 October 2018). Jakarta Sinking: How Subsidence Endangers Indonesia's Capital. Harvard Political Review.

https://harvardpolitics.com/world/jakarta-sinking-how-subsidence-endangers-indones ias-capital/

climatemps.com (n.d.). http://www.jakarta.climatemps.com/precipitation.php

Damuri, Y. R. (2016). Services Sector Development in Indonesia and the Implementation of AEC Measures in Services. CSIS Working Paper Series, Jakarta: Centre for Strategic and International Studies.

Dewan Energi (National Energy Council) (2019). National Energy Policy in Indonesia and Its Alignment to Sustainable Development Goals 7 (SDG7) and Paris Agreement (NDC). Workshop of National Expert SDG Tool for Energy Planning (NEXSTEP), 7.

Dillian, J. (2012). Three-Wheeled Sludge Cart. https://www.csmonitor.com/World/Making-a-difference/Change-Agent/2012/0619/thr ee-wheeled-carts-better-septic-tanks-help-clean-up-Jakarta

Due, J. F., Morris, C. N., Lindbeck, A., Poole, K. E., \& Kay, J. A. (27 September 2018). Government Budget. https://www.britannica.com/topic/government-budget

Dugay, C. (13 August 2012). Indonesia's Top 10 Donors: Responding to the Promise of Transformation. Devex.

https://www.devex.com/news/indonesia-s-top-10-donors-responding-to-the-promise- 
of-transformation-78905

Edelman, D. J. (Ed.) (February 2020). Managing the Urban Environment-Jakarta, Indonesia. Saarbrücken: LAP LAMBERT Academic Publishing.

Edelman, D. J. (Ed.) (January 2019). Managing the Urban Environment-Santo Domingo, the Dominican Republic. Saarbrücken: LAP LAMBERT Academic Publishing.

Edelman, D. J. (Ed.) (February 2018). Managing the Urban Environment-Lima, Peru. Saarbrücken: LAP LAMBERT Academic Publishing.

Edelman, D. J. (Ed.) (January 2016). Managing the Urban Environment-Manila, the Philippines. Saarbrücken: LAP LAMBERT Academic Publishing.

Edelman, D. J. (Ed.) (February 2015). Managing the Urban Environment-Lagos, Nigeria. Saarbrücken: LAP LAMBERT Academic Publishing.

Edelman, D. J. (Ed.) (January 2014). Managing the Urban Environment-Mysore, India. Saarbrücken: LAP LAMBERT Academic Publishing.

Edelman, D. J., Schuster, M., \& Said, J. (2017). Urban Environmental Management in Latin America, 1970-2017. Current Urban Studies, 5, 305-331. https://doi.org/10.4236/cus.2017.53017

Fan, K., \& Nam, S. (2018). Accelerating Geothermal Development in Indonesia: A Case Study in the Underutilization of Geothermal Energy. Consilience: The Journal of Sustainable Development, 19.

Firdayati, M., Indiyani, A., Prihandrijanti, M., \& Otterpohl, R. (2015). Greywater in Indonesia: Characteristic and Treatment Systems. Jurnal Teknik Lingkungan, 21, 98-114. https://www.researchgate.net/publication/329966440 GREYWATER IN INDONESIA CHARACTERISTIC AND TREATMENT SYSTEMS https://doi.org/10.5614/jtl.2015.21.2.1

Garschagen, M., Surtiari, G., \& Harb, M. (2018). Is Jakarta's New Flood Risk Reduction Strategy Transformational? Sustainability, 10, 2934.

https://www.mdpi.com/2071-1050/10/8/2934

https://doi.org/10.3390/su10082934

Gojek (2010). https://www.gojek.com/

Gudmundsson, Y. (2016). Geothermal Project Timelines.

HABITAT (2016). Quito Declaration on Sustainable Cities and Human Settlements for All. Proceedings of the HABITAT III Conference, Quito, Ecuador. http://habitat3.org/wp-content/uploads/NUA-English.pdf

Hasan, M. H., Mahlia, T. M. I., \& Nur, H. (2012). A Review on Energy Scenario and Sustainable Energy in Indonesia. Renewable and Sustainable Energy Reviews, 16, 2316-2328. https://doi.org/10.1016/j.rser.2011.12.007

Hayes, A., \& Setyonaluri, D. (2015). Taking Advantage of the Demographic Dividend in Indonesia: A Brief Introduction to Theory and Practice. Policy Memo, Jakarta: UNFPA Indonesia.

Hivos (27 September 2017). Biogas Indonesia. https://www.hivos.org/program/biogas-indonesia/

Hofman, B., Rodrick-Jones, E., \& Thee, K. W. (2004). Indonesia: Rapid Growth, Weak Institutions. World Bank Report, Washington DC: The World Bank.

https://commodity.com/indonesia/ (accessed 6 February 2020).

https://www.cia.gov/library/publications/the-world-factbook/geos/id.html (accessed 6 February 2020). 
Huang, Y., \& Bocchi, A. M. (2009) Reshaping Economic Geography in East Asia. Washington DC: The World Bank. https://doi.org/10.1596/978-0-8213-7641-6

International Labor Organization-ILO. (n.d.). Informal Economy in Indonesia and Timor-Leste.

http://www.ilo.org/jakarta/areasofwork/informal-economy/lang--en/index.htm

IRENA (2017). Renewable Energy Prospects: Indonesia, a REmap analysis. Abu Dhabi: International Renewable Energy Agency (IRENA). http://www.irena.org/remap

IRIN News (28 May 2015). Living with Dirty Water in Indonesia. Asian Scientist Magazine.

http://www.asianscientist.com/2012/04/health/indonesia-west-java-river-pollution-201 $\underline{21}$

ITDP (15 July 2019). TransJakarta: A Study in Success. Institute for Transportation and Development Policy. https://www.itdp.org/2019/07/15/transjakarta-study-success

ITDP (23 June 2017). TOD Standard. http://www.itdp.org/2017/06/23/tod-standard/

Jong, H. N. (27 July 2019). Indonesia's President Signals a Transition Away from Coal Power.

https://news.mongabay.com/2019/07/indonesias-president-signals-a-transition-away-fr om-coal-power/

jpninfo.com (n.d.). Trash Separator Trash Cans.

Junaidi, A., Nurhamidah, \& Darwizal, D. (2018). Future Flood Management Strategies in Indonesia. MATEC Web of Conferences, 229, Article No. 01014.

https://doi.org/10.1051/matecconf/201822901014

Kahfi, K. (2 January 2020). "Not Ordinary Rain”: Worst Rainfall in over Decade Causes Massive Floods in Jakarta. The Jakarta Post.

https://www.thejakartapost.com/news/2020/01/01/not-ordinary-rain-worst-rainfall-inover-decade-causes-massive-floods-in-jakarta.html

Kompas.com (10 February 2017). Wajah Cihampelas, dari Kolam Renang Khusus Belanda, Patung Superman, hingga "Skywalk".

https://regional.kompas.com/read/2017/02/10/07000031/wajah.cihampelas.dari.kolam. renang.khusus.belanda.patung.superman.hingga.skywalk..?page $=$ all

Kompasiana.com (August 2016). Kesenjangan dan Kemiskinan: Bom Waktu di Indonesia. Indonesia.

https://www.kompasiana.com/musniumar/57b7ba0aa423bde908bfae51/kesenjangan-d an-kemiskinan-bom-waktu-di-indonesia?page $=3$

Kuffer, M., Orina, F., Sliuzas, R., \& Taubenböck, H. (2017). Spatial Patterns of Slums: Comparing African and Asian Cities. Joint Urban Remote Sensing Event (JURSE), Dubai, 6-8 March 2017, 1-4. https://doi.org/10.1109/JURSE.2017.7924587

Leung, K. H. (August 2016). Indonesia's Summary Transport Assessment. Asian Development Bank (ADB).

https://www.adb.org/sites/default/files/publication/217196/ino-paper-15-2016.pdf

LintasDaerah.com (n.d.). Boyolali’s MUSRENBANG Approved Proposals from Various Fields.

https://lintasdaerah.com/dalam-MUSRENBANG-boyolali-setujui-usulan-dari-berbagai -bidang/

Luo, P., Kang, S., Apip, Zhou, M., Lyu, J., Aisyah, S., Binaya, M., Regmi, R. K., \& Nover, D. (2019). Water Quality Trend Assessment in Jakarta: A Rapidly Growing Asian Megacity. PLoS ONE, 14, e0219009.

https://journals.plos.org/plosone/article?id=10.1371/journal.pone.0219009 
https://doi.org/10.1371/journal.pone.0219009

Lyons, K. (27 August 2019). Why Is Indonesia Moving its Capital City? Everything You Need to Know. The Guardian.

https://www.theguardian.com/world/2019/aug/27/why-is-indonesia-moving-its-capital -city-everything-you-need-to-know

Maclean, D. (29 May 2014). Flooding and Jakarta's Urban Poor. The Diplomat. https://thediplomat.com/2014/05/flooding-and-jakartas-urban-poor/

McKnight, J. (17 February 2017). California Architecture Students Design Shelters for LA's Growing Homeless Population. Dezeen. www.dezeen.com/2017/02/22/california-architecture-students-design-shelters-for-los-a ngeles-growing-homeless-population/

Nabilah, G. (2018). Inclusive Public Space for Productive Activity. Jakarta.

Nekkei Asian Review (2018). Shenzhen and Jakarta Shine in City Economy Forecasts for 2030.

Nelson, K. G. (7 January 2016). What Kenya's Biggest Slum Can Teach Us about Saving Cities from Floods. Ensia.

https://ensia.com/features/what-kenyas-biggest-slum-can-teach-us-about-saving-cities -from-floods/

Octavianti, T., \& Charles, K. (2018) The Evolution of Jakarta's Flood Policy over the Past 400 Years: The Lock-in of Infrastructural Solutions. Environment and Planning C: Politics and Space, 37, 1102-1125. https://doi.org/10.1177/2399654418813578

OECD Statistics Directorate (n.d.). https://stats.oecd.org/glossary/detail.asp?ID=5901

Oliver, S. (19 June 2012). Three-Wheeled Carts, Better Septic Tanks Help Clean up Jakarta. The Christian Science Monitor.

https://www.csmonitor.com/World/Making-a-difference/Change-Agent/2012/0619/Th ree-wheeled-carts-better-septic-tanks-help-clean-up-Jakarta

Perjanjian Kinerja (2019). Jakarta's Budget in 2020. 2019 Government Performance Agreement.

Renaldi, A. (23 July 2018). Poverty Isn't Decreasing, Indonesia's Official Poverty Line Is Just Too Low.

https://www.vice.com/en asia/article/ev8z7w/poverty-isnt-decreasing-indonesias-offici al-poverty-line-is-just-too-low

Rosane, O. (3 May 2019). Indonesia will Move its Capital from Fast-Sinking Jakarta. ecowatch.com.

https://www.ecowatch.com/indonesia-to-move-capital-jakarta-2636197365.html

Salikha, A. (29 January 2018).

https://seasia.co/2018/01/29/meet-the-10-megadiverse-countries-in-the-world

Sari, S. P., \& Suhendri (2018). Potential of Rainwater System for Domestic Building in Jakarta. IOP Conference Series: Earth and Environmental Science, 152, Article ID: 012002. https://iopscience.iop.org/article/10.1088/1755-1315/152/1/012002 https://doi.org/10.1088/1755-1315/152/1/012002

Scruggs, G. (12 February 2020). There Are 10,000 Cities on Planet Earth. Half Didn't Exist 40 Years Ago. Next City.

https://nextcity.org/daily/entry/there-are-10000-cities-on-planet-earth-half-didnt-exist -40-years-ago

Simon, M. (2 May 2019). Jakarta Is Sinking. Now Indonesia Has to Find a New Capital. Wired. https://www.wired.com/story/jakarta-is-sinking/ 
Solo Kota Kita (January 2020).

Susilo, Y. O., Santosa, W., Joewono, T. B., \& Parkiset, D. (2007). A Reflection of Motorization and Public Transport in Jakarta Metropolitan Area. IATSS Research, 31, 59-68. https://doi.org/10.1016/s0386-1112(14)60184-9

Tharakan, P. (2015). Summary of Indonesia's Energy Sector Assessment. Asian Development Bank Papers on Indonesia, 9.

The Jakarta Post (25 July 2015a). Editorial: We Can't Stop Urbanization. https://www.thejakartapost.com/news/2015/07/25/editorial-we-can-t-stop-urbanizatio n.html

The Jakarta Post (28 May 2019a). Slums Remain a Fact of Life in Jakarta, Ministry Finds. https://www.thejakartapost.com/news/2019/05/28/half-of-jakarta-is-slum-ministry-say s.html

The Jakarta Post (30 July 2019b). Singapore Remains Indonesia's Top Foreign Investor in First Half.

https://www.thejakartapost.com/news/2019/07/30/singapore-remains-indonesias-top-f oreign-investor-in-first-half.html

The Jakarta Post (4 December 2015b). Communal System Solution for Wastewater Treatment.

https://www.thejakartapost.com/news/2015/12/04/communal-system-solution-wastew ater-treatment.html

The Jakarta Post (9 November 2017). Bandung's Teras Cihampelas Redefines Pedestrian Walkway.

https://www.thejakartapost.com/travel/2017/02/09/bandungs-teras-cihampelas-redefin es-pedestrian-walkway.html

The World Bank (2016). Indonesia's Rising Divide. http://pubdocs.worldbank.org/en/16261460705088179/Indonesias-Rising-Divide-Engli $\underline{\text { sh.pdf }}$ https://doi.org/10.1596/24765

The World Bank (2017). Improving Service Levels and Impact on the Poor: A Diagnostic of Water Supply, Sanitation, Hygiene, and Poverty in Indonesia (English). Washington DC: The World Bank Group.

http://documents.worldbank.org/curated/en/416251507873416293/Improving-service-1 evels-and-impact-on-the-poor-a-diagnostic-of-water-supply-sanitation-hygiene-and-p overty-in-Indonesia https://doi.org/10.1596/28505

The World Bank (2019). Country Overview-Indonesia. https://www.worldbank.org/en/country/indonesia/overview\#1

United Nations (2020). World Urbanization Prospects: United Nations Population Estimates and Projections of Major Urban Agglomerations.

Urs, R. (3 January 2019). GOJEK’s Impact on Indonesia’s Gig Economy. Medium. Gojek Product Tech.

https://blog.gojekengineering.com/gojeks-impact-on-indonesia-s-gig-economy-990a60 cd23b9

Village Enterprise (n.d.). What We Do. https://villageenterprise.org/what-we-do/

water.org (n.d.). Indonesia's Water Crisis-Indonesia's Water Problems in 2019. http://water.org. https://water.org/our-impact/indonesia/

Widodo, T. (2006). From Dutch Mercantilism to Liberalism: Indonesian Historical Perspective. Jurnal Ekonomi dan Bisnis Indonesia, 323-343. 
Workman, D. (26 December 2017).

http://www.worldstopexports.com/indonesias-top-15-import-partners/

World Population Review-Indonesia (2020).

http://worldpopulationreview.com/countries/indonesia-population/

World Population Review-Jakarta (2020).

http://worldpopulationreview.com/world-cities/jakarta/population/

Zhang, Y., Tunlivate, V., Aristanti, C., \& Wu, Y. (1 June 2013). Indonesia-Toward Universal Access to Clean Cooking. The World Bank.

http://documents.worldbank.org/curated/en/105441468044144806/Indonesia-Towarduniversal-access-to-clean-cooking 